\title{
Changes in volatile composition during the processing and storage of black ripe
} olives

Antonio López-López, Amparo Cortés-Delgado, Antonio de Castro, Antonio Higinio Sánchez, Alfredo Montaño*

Food Biotechnology Department, Instituto de la Grasa-CSIC, Utrera road, km 1, 41013 Seville, Spain

*Tel.: +34 95 4611550, fax: +34954616790, e-mail corresponding author (A.

Montaño): amontano@cica.es

E-mail addresses for co-authors:

Antonio López-López: all@cica.es

Antonio de Castro: adcastro@ig.csic.es

Antonio Higinio Sánchez: ahiginio@ig.csic.es

Amparo Cortés-Delgado: acortes@ cica.es

Running title: Volatile composition of black ripe olives 


\begin{abstract}
The present study revealed the effects of each step of black ripe olive processing (preservation, darkening, packing + sterilization) and storage on the volatile composition of two olive cultivars (Manzanilla and Hojiblanca). The preservation step enriched the volatile profile of the olives, mainly in ethyl acetate, methyl acetate, and ethanol. The darkening step produced the total or partial elimination of $55-65 \%$ of the volatiles identified before this step. Around $70 \%$ of the volatiles in the final products corresponded to compounds that were formed or increased significantly as a result of the sterilization treatment at $121^{\circ} \mathrm{C}$. Although differences in the volatile compositions and contents between Manzanilla and Hojiblanca were found, the dominant volatiles in both cultivars were benzaldehyde, dimethyl sulfide and ethyl acetate. Storage for 8 months had little influence on their volatile profiles, although the stability of individual volatiles in Manzanilla was better than that in the Hojiblanca cultivar.
\end{abstract}

Keywords: black ripe olives, processing, storage, volatile composition, Manzanilla cultivar, Hojiblanca cultivar 


\section{Highlights}

- The changes in volatiles during the processing of black ripe olives were studied.

- The preservation step increased the total amount and number of volatiles.

- The darkening step produced considerable losses in the volatile composition.

- The sterilization treatment led to a noticeable enrichment in volatile compounds.

- Storage for 8 months had little effect on the volatile profile of black ripe olives. 


\section{Introduction}

Black ripe olives, which are also known as Californian-style black olives or olives darkened by oxidation, are one of the most important types of table olives commercialized worldwide. This processing style accounts for $40-50 \%$ of all table olives exported from Spain, the world's main producer and exporter of table olives (ASEMESA, 2019). Once in the production plant, the olives, mostly in the green and cherry stages of ripening, are directly processed or (more commonly) preserved before oxidation (Sánchez, García, \& Rejano, 2006). Preservation is usually done in brine or an acidified solution (de Castro, García, Romero, Brenes, \& Garrido, 2007). Once the stored fruits are sorted and graded, they are treated with one to several lye solutions (1$4 \% \mathrm{NaOH}, \mathrm{w} / \mathrm{v})$. Between lye treatments, the fruits are suspended in water through which air is bubbled. During this operation, the fruits darken progressively. After darkening, the olives are washed several times with water to remove most of the residual lye and lower the $\mathrm{pH}$ in the flesh to around 8 units, and then placed in $0.1 \%$ $(w / v)$ of ferrous gluconate or ferrous lactate to maintain their black color. Finally, the olives are packed with a brine containing 2-4\% $\mathrm{NaCl}$ and $10-40 \mathrm{mg} \mathrm{L}^{-1}$ of iron (added as ferrous gluconate or ferrous lactate) to prevent deterioration of their black color, and heat sterilized (generally at $121-126^{\circ} \mathrm{C}$ ). To ensure microbiological stability, a minimum value for accumulated lethality of $15 \mathrm{~F}_{0}$ should be reached (IOOC, 2004). Volatile compounds give rise to the aroma of food products and, therefore, are important factors in consumer perception and acceptance of foods. It is well known that processing technology greatly influences the volatile composition of olives and, 
consequently, the flavor of the final product (Sabatini \& Marsilio, 2008). In recent years, studies on the volatile composition of table olives have been relatively numerous (Bleve et al., 2015; Cano-Lamadrid et al., 2015; Cortés-Delgado et al., 2016; De Angelis et al., 2015; de Castro, Sánchez, Cortés-Delgado, López-López, \& Montaño, 2019; de Castro et al., 2018; López-López, Sánchez, Cortés-Delgado, de Castro, \& Montaño, 2018; Martorana et al., 2017; Randazzo et al., 2017; Sánchez et al., 2017, 2018; Selli, Kelebek, Kesen, \& Sonmezdag, 2018). However, although optimal processing conditions and microbial spoilage have been extensively studied in black ripe olives, literature concerning volatile composition is almost nonexistent for this product. In fact, to the best of our knowledge, only one publication on this subject has been found to date (Sansone-Land, Takeoka, \& Shoemaker, 2014). In that publication, the authors found clear differences among the volatile compositions of black ripe olives produced in different countries, which could be attributed to a number of factors, including olive cultivar, location of growth, processing method, storage conditions after processing, and age of the samples (that is, the length of storage after packing). As a consequence, it is not surprising that differences in aroma and flavor characteristics among black ripe olives from different countries (Lee, Kitsawad, Sigal, Flynn, \& Guinard, 2012) and cultivars (López-López, Sánchez, Montaño, Cortés-Delgado, \& Garrido-Fernández, 2019) have been found.

The technique of solid-phase microextraction (SPME) followed by gas chromatography-mass spectrometry (GC-MS) is frequently used in the field of food analysis for a variety of purposes, including aroma profiling, determination of contaminants, chemical fingerprinting, metabolomics investigations, and determination 
of nutraceutical values, among various other applications (Reyes-Garcés et al., 2018). In the case of table olives, SPME-GC-MS has been successfully applied to study the volatile composition of unfermented "Campo Real" table olives (Navarro, De Lorenzo, \& Pérez, 2004), Greek-style table olives (Bleve et al., 2015; De Angelis et al., 2015; Randazzo et al., 2017), “alcaparras” table olives (Malheiro, de Pinho, Casal, Bento, \& Pereira, 2011), and Spanish-style table olives (Cano-Lamadrid et al., 2015; CortésDelgado et al., 2016; de Castro et al., 2018, 2019; López-López et al., 2018; Martorana et al., 2017; Sánchez et al., 2017, 2018).

In this work we have used SPME-GC-MS to study the changes in volatile components during the typical Californian-style processing with the aim of determining the origin of each volatile compound in the final product and its stability during storage. The study was carried out with olives of the Hojiblanca and Manzanilla cultivars grown in the same location and processed using the same processing method. In that way, the effect of the olive cultivar on its volatile composition was also disclosed.

\section{Materials and methods}

\subsection{Black ripe olive processing}

Olives (Manzanilla and Hojiblanca cultivars) were grown at Lora de Estepa (Seville province, Spain) and harvested at their mature-green stage. Fifteen $\mathrm{kg}$ of each cultivar were preserved in $25 \mathrm{~L} \mathrm{PVC}$ vessels for 3 months with an acidified solution containing $2.4 \%(\mathrm{v} / \mathrm{v})$ acetic acid before processing. Then the olives were subjected to darkening 
following the habitual procedure for the elaboration of black ripe olives. Briefly, olives were treated in a horizontal stainless steel cylindrical container $(0.4 \mathrm{~m}$ diameter, $0.7 \mathrm{~m}$ length) with a lye solution of $3 \%(\mathrm{w} / \mathrm{v}) \mathrm{NaOH}$, which progressively penetrated the flesh until the alkali reached the pit. Next, the lye was removed and the olives were washed ( 2 water washings, each of $24 \mathrm{~h}$ duration) until the $\mathrm{pH}$ reached 8.0. During the washing treatment, additions of $3 \mathrm{~N} \mathrm{HCl}$ and $\mathrm{CO}_{2}$ injections into the containers were carried out to neutralize the excess $\mathrm{NaOH}$. During the lye treatment and washing, air was injected through the bottom of the container. Then, a $0.1 \%(\mathrm{w} / \mathrm{v})$ ferrous gluconate solution was added to fix the black color. The darkened olives were packed in "A314" glass bottles (145 g of olives plus $170 \mathrm{~mL}$ of brine capacity) and covered with a $3.5 \%$ (w/v) $\mathrm{NaCl}$ solution containing $0.02 \%(\mathrm{w} / \mathrm{v})$ ferrous gluconate as cover brine, and the bottles were subjected to sterilization for $17 \mathrm{~min}$ at $121^{\circ} \mathrm{C}$ in a computer-controlled retort (Steriflow, SAS, Paris, France). This sterilization process was previously calculated to achieve the recommended value of accumulated lethality $\left(15 \mathrm{~F}_{0}\right)$. The sterilized packed olives were stored at room temperature.

\subsection{Sampling}

After 3 months of preservation in $2.4 \%$ acetic acid, samples of the preservation liquids from the two vessels were taken for analyses of physico-chemical and microbiological characteristics. Analyses of volatile compounds in olive pulp were performed before preservation (fresh green olives), after 3 months of preservation, after the darkening step, after packing plus sterilization, and after 8 months of storage. The initial sampling 
of the packed product was performed after 15 days (and not immediately after sterilization treatment) to ensure that the required equilibrium inside the bottles had been reached.

\subsection{Physicochemical and microbiological analyses}

The $\mathrm{pH}$, titratable acidity, and combined acidity were measured following the routine procedures used in our laboratories (Cortés-Delgado et al., 2016). Microbiological analyses for monitoring the populations of yeasts, acetic acid bacteria and lactic acid bacteria were carried out according to de Castro et al. (2007).

\subsection{Analysis of volatile compounds}

The volatile compounds were extracted using the same procedure as reported by Cortés-Delgado et al. (2016), except that the extraction temperature and extraction time were set at $40{ }^{\circ} \mathrm{C}$ and $30 \mathrm{~min}$, respectively. Olives (approximately $150 \mathrm{~g}$ ) were pitted and then homogenized in a blender at room temperature $\left(22-24^{\circ} \mathrm{C}\right)$. An aliquot $(2.5 \mathrm{~g})$ of homogenized pulp was placed in a $15 \mathrm{~mL}$ glass vial, and $7.5 \mathrm{~mL}$ of $30 \%(\mathrm{w} / \mathrm{v}) \mathrm{NaCl}$ were added. The vial was closed and placed in a water bath adjusted to $40{ }^{\circ} \mathrm{C}$ for $15 \mathrm{~min}$ in order to reach equilibrium. The extraction was performed by exposing a divinylbenzene/carboxen/polydimethylsiloxane (DVB/CAR/PDMS) StableFlex fiber (1 $\mathrm{cm}, 50 / 30 \mu \mathrm{m}$; Supelco, Bellefonte, PA) in the headspace of the sample at $40{ }^{\circ} \mathrm{C}$ for 30 min. The samples were gently vortexed during equilibration and extraction at $600 \mathrm{rpm}$ 
using a magnetic stirrer. After extraction, the fiber was removed from the vial and immediately inserted into the injection port of the $\mathrm{GC}$ for desorption at $250{ }^{\circ} \mathrm{C}$ for 15 min. All analyses of the volatile compounds were made in triplicate. GC-MS analyses were performed following the procedure reported by Cortés-Delgado et al. (2016). The GC peak area of each compound was obtained from the ion extraction chromatogram (IEC) by selecting target ions for each one. These ions corresponded to base ions ( $\mathrm{m} / \mathrm{z}$ $100 \%$ intensity), molecular ions $(\mathrm{M}+)$ or another characteristic ion for each molecule. Hence, some peaks that could be co-eluted in scan mode can be integrated with a value of resolution greater than 1. Compound identification was based on mass spectra matching with the standard NIST 08 MS library and on the comparison of retention indices (RI) sourced from the NIST Standard Reference Database and from authentic reference standards when available.

\subsection{Statistical analyses}

All the data were compiled and calculated using a combination of Microsoft Excel 2010 (Microsoft Corporation, Redmond, WA) and XLSTAT v. 2016 (Addinsoft, Paris, France). To compare the effect of each processing step and storage on the individual volatiles (peak areas) the paired Student's $t$-test was used. Significant differences were determined at the $\mathrm{p}<0.05$ level.

\section{Results and discussion}


The identified headspace volatile compounds and their average peak areas after each processing step and after 8 months of storage are shown in Tables S1 and S2 for Manzanilla and Hojiblanca cultivars, respectively. A total of 62 and 76 volatile compounds were identified in Manzanilla and Hojiblanca olives, respectively. The volatile components included alcohols, carbonyl compounds, esters, heterocyclic compounds, hydrocarbons, phenols, terpenes, organosulfur compounds, acids, and ethers. Both in Manzanilla and Hojiblanca, the total peak area of identified volatile compounds showed significant changes during processing and storage (Figure 1). The changes in chemical classes of the identified volatiles, except acids, are shown in Figure 2. Some differences in the volatile composition and content between the two cultivars were noticed considering qualitative and quantitative results, as mentioned below.

\subsection{Volatile compounds in fresh fruit}

The chemical composition of fresh olive headspace from both cultivars was predominated by alcohols and carbonyl compounds (Figure 2). Regarding individual volatile compounds, 21 compounds were identified in the Manzanilla cultivar, whereas 28 volatiles were identified in Hojiblanca. The major volatiles were: $(Z)-3$-hexen-1-ol (17.8\% in Manzanilla, 33\% in Hojiblanca); (E)-2-hexenal (16\%, 16\%), 3-hexenal (sum of two isomers, $16.1 \%, 12.9 \%), 1$-penten-3-one $(9.8 \%, 8.9 \%)$, and 1-penten-3-ol (14\%, 6.4\%) (Tables 1 and 2). All of these compounds along with other minor C6 and C5 compounds (such as hexanal, 1-hexanol, and 1-pentanol) are known to be formed by endogenous olive enzymes through the lipoxygenase (LOX) pathway from linoleic and 
linolenic acids (Ridolfi, Terenziani, Patumi, \& Fontanazza, 2002). These enzymes may be activated during sample preparation for volatile analysis as a result of the operations of pitting and homogenization.

Since the degree of ripening, harvesting period, geographical origin, and extraction conditions (including the temperature of homogenization and the extraction temperature) were similar for the two olive cultivars in the present study, the different outcomes can be attributed solely to their varietal background, which results in different volatile compositions. Thus, the alcohols 1-pentanol, $(E)$-2-penten-1-ol, $(E)$-3-hexen-1ol, and (E)-2-hexen-1-ol, all of them derived by LOX action as well as benzyl alcohol, (E,E)-2,4-heptadienal, pseudocumene, and (Z)-3-hexenyl methyl ether were found in Hojiblanca only. In fact, the total peak area from the C5 and C6 compounds derived by LOX action (data not shown) was higher in Hojiblanca compared to Manzanilla. This would indicate that Hojiblanca showed a higher enzymatic activity, as there appears to be a direct relationship between the quantity of C5 and C6 volatile compounds (aldehydes, alcohols, and ketones) and LOX activity in the olives (Ridolfi et al., 2002). In addition, the presence of $(E, E)-2,4$-heptadienal could be due to autoxidation reactions which did not occur in Manzanilla, presumably due to its higher content of natural antioxidants (e.g. phenolic compounds) in comparison with Hojiblanca (Ramírez, Medina, García, Brenes, \& Romero, 2017). The presence of (Z)-3-hexenyl methyl ether (around 1\%) in Hojiblanca is also worth noting. To the best of our knowledge, the occurrence of ethers in olives has not been reported in the literature to date. Further research is needed to know whether this ether could be a potential marker candidate to differentiate the Hojiblanca cultivar from other olive cultivars. 
3.2. Volatile compounds in olives after the preservation step

After preservation in acid solution for 3 months, an increase in total peak area from headspace volatile compounds (without considering acetic acid) was found for both cultivars compared to fresh fruit (Figure 1), with esters and alcohols comprising the most abundant chemical classes (Figure 2). A total of 29 and 34 volatiles were identified after preservation in Manzanilla and Hojiblanca, respectively, with ethyl acetate $(28 \%, 29 \%)$, ethanol $(6.8 \%, 6.9 \%)$, and methyl acetate $(4.3 \%, 3.9 \%)$ being the dominant volatiles (Tables 1 and 2). These compounds appeared during the preservation period, presumably as a result of microbial action. Yeasts and acetic acid bacteria were the only microorganisms detected in the liquid medium after preservation. This was observed in the two cultivars and the microbial counts were quite similar in both cases (Table S3). Lactic acid bacteria were not detected in any case. Consequently, ethanol was likely produced by yeast fermentation exclusively. Acetic acid bacteria are known for their ability to partially oxidize ethanol (to produce acetic acid) and a variety of sugars (Mamlouk \& Gullo, 2013). Acetate esters could be synthesized by an alcoholacyl-transferase which catalyzes the esterification of volatile alcohols with acetyl-CoA molecules (derived from acetic acid and coenzyme A) to produce volatile esters and free CoA-SH (Sabatini \& Marsilio, 2008).

In addition to the above-mentioned compounds, other volatiles were formed during preservation, although in lesser amounts. Among them, octane, 1-octanol, heptanal, octanal and nonanal are worth mentioning, as they can be considered indicators of lipid 
oxidation and appeared as a result of the preservation step both in Manzanilla and Hojiblanca (Tables S1 and S2). The unsaturated aldehydes (E)-2-octenal and (E)-2decenal, other typical oxidation volatiles, were formed in Manzanilla olives but were not detected in Hojiblanca. This finding appeared to indicate a higher susceptibility to lipid oxidation in the case of the Manzanilla cultivar during the preservation step in acid solution, which is in agreement with our previous results in case of black ripe olive processing (López-López, Rodríguez-Gómez, Cortés-Delgado, Montano, \& GarridoFernández, 2009) or Spanish-style green table olive processing (Cortés-Delgado et al., 2016; Sánchez et al., 2018). This explanation is in contrast with that mentioned for raw olives in the previous section. During the preservation step, the content of natural antioxidants such as polyphenols in olive pulp gradually decreases (Ramírez, Medina, García, Brenes, \& Romero, 2017). As a consequence, the protective effect of polyphenols against lipid oxidation reactions could be less effective compared to raw olives. Octane, 1-octanol and nonanal could be formed by the breakdown of oleato 9/10-OOH, heptanal and (E)-2-octenal by the decomposition of linoleato 11-OOH, octanal from oleate 11-OOH, and (E)-2-decenal from oleato 9-OOH (Frankel, 1983). Phenylethyl alcohol, phenylacetaldehyde, benzaldehyde, and (Z)-3-hexenyl acetate increased significantly as a result of the preservation stage in both cultivars (TablesS1 and S2). Phenylethyl alcohol and phenylacetaldehyde could be formed by yeasts from L-phenylalanine via the Ehrlich pathway (Eshkol et al., 2009). In this metabolic pathway, L-phenylalanine is transaminated to phenylpyruvate by a transaminase, decarboxylated to phenylacetaldehyde by a decarboxylase, and subsequently reduced to phenylethyl alcohol by a dehydrogenase. Benzaldehyde could be produced by the 
chemical oxidation of the microbially produced phenylpyruvate, although this reaction appears to be enhanced at alkaline $\mathrm{pH}$ in the presence of oxygen (Nierop Groot \& de Bont, 1998). Since the $\mathrm{pH}$ of olives during the preservation step was about 4 (Table S3), it is more likely that benzaldehyde could be enzymatically produced by a peroxidase. Tzika, Sotiroudis, Papadimitriou, \& Xenakis (2009) extracted and characterized a peroxidase from olives (cv. Koroneiki) and found that its $\mathrm{pH}$ optimum values ranged between 4.0 and 6.0. (Z)-3-hexenyl acetate could be synthesized by esterification of (Z)3-hexen-1-ol with acetyl-CoA, which is supported by a significant decrease in the peak area of (Z)-3-hexen-1-ol (Tables S1 and S2).

On the other hand, most alcohols and carbonyl compounds formed by the LOX pathway in fresh olives were undetected or their concentrations decreased considerably after the preservation step in both cultivars (Tables S1 and S2), which could be attributed to the degradation or inactivation of endogenous enzymes (e.g. acyl hydrolase, lipoxygenase, and hydroperoxide lyase) due to the acidic $\mathrm{pH}$ of olive pulp after preservation $(\mathrm{pH} \approx 4$, Table S3). Ridolfi et al. (2002) found almost no activity of olive lipoxygenases at pH 4.

3.3. Volatile compounds in olives after the darkening step

As a result of the darkening step (which included lye treatment + air oxidation, neutralization, and color fixation) there was a considerable decrease in the total peak area of headspace volatile compounds (Figure 1). Regardless of the cultivar, hydrocarbons and carbonyl compounds were the dominant chemical families in the profile of olives after this step (Figure 2). The number of volatiles identified after 
darkening was 29 and 34 for Manzanilla and Hojiblanca cultivars, respectively, with octane $(56.0 \%, 15.4 \%)$, 3-methylbutanal $(10.1 \%, 12 \%)$, and 2-methylbutanal (10\%, 7.6\%) comprising the most prominent compounds in both cultivars (Tables 1 and 2). Toluene, $p$-xylene, (Z)-3-hexenyl methyl ether, and (Z)-3-hexenyl acetate were also relatively abundant (> 5\%) in Hojiblanca olives.

Both in Manzanilla and Hojiblanca olives, only a few volatiles appeared (2methylbutanal, 3-methylbutanal, 3-ethylpyridine, 3-ethyl-4-methylpyridine) or increased significantly (octane, benzaldehyde) as a result of darkening step (Tables S1 and S2). The darkening process in black ripe olives has been mainly related to chemical oxidation browning reactions, involving the oxidation of natural $o$-diphenols in olives to $o$-quinones, followed by the transformation of $o$-quinones into different dark compounds (Marsilio, Campestre, \& Lanza, 2001). Secondary reactions of the $o$ quinones can include the Strecker degradation of amino acids at room temperature (Rizzi, 2006). Thus, the formation of the Strecker aldehydes 2-methylbutanal and 3methylbutanal (derived from the amino acids isoleucine and leucine, respectively) is an indication that such reactions induced by polyphenol oxidation occur during the darkening step of black ripe olives. The presence of the above-mentioned alkylpyridines is surprising, as pyridines are normally found in foods which have undergone thermal treatments. We confirmed this result by analyzing samples from two other elaborations of black ripe olives carried out in our laboratories (data not shown). Pyridines in foods are formed by the condensation reaction of aldehydes, ketones, $\alpha, \beta$-unsaturated carbonyl compounds, or various derivatives of such compounds with ammonia or amino acids (Suyama \& Adachi, 1980). 
As mentioned above, octane is a secondary oxidation product from the oxidation of oleic acid. However, the formation of or significant increases in other typical oxidation products such as 1-octanol, octanal, nonanal, $(E)$-2-octenal, and $(E)$-2-decenal were not found. This is explained by the fact that their formation might be counteracted by their degradation during lye treatment or due to the effect of $\mathrm{Fe}^{2+}$ (used to fix the black color) which is oxidized to $\mathrm{Fe}^{3+}$ while reducing the primary oxidation products. In fact, a marked reduction in $K_{270}$ (parameter related to the formation of trienes and other secondary oxidation products) of ripe olive fat during the darkening step has been previously reported (López-López et al., 2009). Benzaldehyde could be formed from benzyl alcohol by oxidation, which is supported by a significant decrease in the peak area of benzyl alcohol in both cultivars (Tables S1 and S2). Phenylaceldehyde is another precursor that is able to form benzaldehyde by oxidation (Chu \& Yaylayan, 2008), and this is also supported by a significant decrease in (Manzanilla) or elimination of (Hojiblanca) the corresponding peak area. However, no evidence of further benzaldehyde oxidation to form benzoic acid was found, as this acid was not detected after darkening.

Regarding the compounds that were totally or partially eliminated during the darkening step, it is worth mentioning that acetic acid, isopentanol, and the esters methyl acetate and ethyl acetate disappeared from both cultivars; whereas ( $Z$-)-3-hexenyl acetate, hexanal, 1-hexanol, (Z)-3-hexen-1-ol, benzyl alcohol, and phenylethyl alcohol decreased significantly (fold change 1.3-7.1, Tables S1 and S2). Other compounds which were totally or partially lost were ethanol, phenylacetaldehyde, methyl salicylate, and dimethyl sulfide. Among the different reaction mechanisms that explain the loss of 
volatiles during the darkening step we can mention neutralization (e.g. acetic acid due to lye treatment), hydrolysis (e.g. acetate esters due to lye treatment), and oxidation by air (e.g. ethanol to yield acetaldehyde, dimethyl sulfide to form dimethyl sulfoxide, which can be further oxidized to dimethyl sulfone, and benzyl alcohol to form benzaldehyde, as mentioned above). However, losses by other mechanisms (evaporation, leaching into the surrounding liquid) cannot be ruled out.

3.4. Volatile compounds in olives after the packing step

The packing step (which included the addition of fresh cover brine and a sterilization treatment) caused a significant increase in the total peak area of headspace volatile compounds compared to data before packing (Figure 1). In both cultivars, there were significant increases in most chemical classes including carbonyl compounds, esters, heterocyclic compounds, and organosulfur compounds, whereas only hydrocarbons decreased; and carbonyl compounds comprised the predominant chemical class after packing (Figure 2). Regarding individual compounds, 47 and 55 volatiles were identified after the packing of Manzanilla and Hojiblanca olives, respectively, with benzaldehyde $(16 \%, 36 \%)$, dimethyl sulfide $(16 \%, 11 \%)$, and ethyl acetate $(10 \%, 12 \%)$ being the most abundant compounds (Tables 1 and 2). The aldehydes 2-methylbutanal and 3-methylbutanal were also relatively abundant in both cultivars (3.8-8.2\%). Most of the volatiles identified after packing corresponded to compounds that were formed or increased significantly in their concentrations, mostly due to the heat treatment of sterilization. With regards to the volatiles formed (> $40 \%$ of the volatiles 
identified) both in Hojiblanca and Manzanilla olives (Tables S1 and S2), we can highlight: 2-methylpropanal, 2-butenal, pentanal, 2-ethyl-2-butenal, (E,E)-2,4heptadienal, 4-ethylbenzaldehyde, (E,E)-2,4-decadienal, (E)-cinnamaldehyde, methyl acetate, ethyl acetate, methyl nicotinate, methyl 2-formylbenzoate, furfural, 3vinylpyridine, vanillin, 6-methyl-5-hepten-2-one, and dimethyl sulfoxide. Among these compounds, the highest production corresponded to ethyl acetate $(10 \%, 12 \%)$ followed by 3-vinylpyridine $(2.6 \%, 4.2 \%)$ (Tables 1 and 2$)$. The formation of aldehydes such as 2-butenal, pentanal, (E,E)-2,4-heptadienal, and (E,E)-2,4-decadienal would be indicative of oxidation reactions from linoleic and linolenic acids (Frankel, 1983). Other aldehydes formed as secondary oxidation products of fatty acids were 2-heptenal, (E)-2-octenal, and (E)-2-decenal, which were formed in Hojiblanca or increased significantly in Manzanilla (Tables S1 and S2). It is noteworthy that 2-vinyl-2-butenal was formed in a relatively high amount in Manzanilla (8.8\%), but this aldehyde was not detected in Hojiblanca olives.

A higher number of pyridines were detected in Hojiblanca ripe olives compared to Manzanilla ripe olives. Thus, pyridine and 3-methylpyridine were formed in Hojiblanca, but not in Manzanilla. As mentioned above, pyridines could be formed by the condensation reaction of aldehydes, ketones, $\alpha, \beta$-unsaturated carbonyl compounds, or various derivatives of such compounds with ammonia or amino acids (Suyama \& Adachi, 1980). These heterocyclic compounds, specifically, 3-ethylpyridine, 3vinylpyridine and 3-ethyl-4-methylpyridine have been previously identified in commercial black ripe olives (Sansone-Land et al., 2014). 
Furfural could be formed as an intermediate product of the Maillard reaction when pentoses are involved (Martins, Jongen, \& van Boekel, 2001). Furfuryl alcohol was found in Hojiblanca olives, but was not detected in Manzanilla. This furfural derivative might be formed during storage (it must be taken into account that sampling after packing was performed after 15 days of storage) from the reduction of furfural in the presence of $\mathrm{Fe}^{2+}$, as supported by the changes found in furfural and furfuryl alcohol at longer storage, as mentioned later.

Vanillin could be derived from the thermal and oxidative breakdown of ferulic acid (Fiddler, Parker, Wasserman, \& Doerr, 1967). 6-Methyl-5-hepten-2-one is regarded as a marker compound for the degradation of carotenoids (Cremer \& Eichner, 2000). Dimethyl sulfoxide could be formed through the oxidation of dimethyl sulfide, as mentioned above.

Apart from the volatiles formed, more than $25 \%$ of the identified volatiles corresponded to compounds which significantly increased their concentration as a result of packing (Tables S1 and S2). Thus, in both cultivars, there was a significant increase in the peak areas of the following volatiles: 2-methylbutanal, 3-methylbutanal, benzaldehyde, hexanal, octanal, 3-ethylpyridine, 3-ethyl-4-methylpyridine, and phenol. The increase in the Strecker aldehydes 2-methylbutanal and 3-methylbutanal is another indication that the Maillard reaction occurred during the sterilization treatment (Cremer \& Eichner, 2000); whereas the increase in hexanal and octanal would be related to the oxidation of linoleic and oleic acids, respectively. The noticeable increases in 3-ethylpyridine (with fold changes of 2.6 and 5.9 for Manzanilla and Hojiblanca, respectively) and 3-ethyl-4methylpyridine (fold changes of 3.8 and 10.8), along with the formation of other 
pyridines as mentioned above, confirm that high temperatures play an important role in their formation.

Among the above-mentioned volatiles, benzaldehyde merits a more detailed discussion. It is striking that the amount of benzaldehyde increased greatly with packing (fold changes of 25.7 and 79.1 for Manzanilla and Hojiblanca, respectively). Benzaldehyde was previously found in "Campo Real" unfermented table olives, a typical and specialist product from Comunidad de Madrid (Spain), when olives were subjected to a sterilization treatment (Navarro et al., 2004). Benzaldehyde could arise through the degradation of phenylpyruvate, which may be generated chemically from phenylalanine. The enzymatic generation of phenylpyruvate suggested in the preservation step (section 3.2) would not be possible in the packing step due to the sterilization treatment. It has been demonstrated that in the presence of appropriate carbonyl compounds (e.g. 4,5-epoxy-2-decenal, which has been identified as a secondary product of thermally oxidized trilinolein; Frankel, 1983), phenylalanine can undergo transamination and generate phenylpyruvic acid, which is easily oxidized to produce benzaldehyde and phenylacetaldehyde (Zamora, Navarro, Gallardo, \& Hidalgo, 2006). In turn, phenylacetaldehyde could be oxidized to produce benzaldehyde according to a free radical initiated oxidative mechanism, as proposed by Chu and Yaylayan (2008).

Interestingly, benzoic acid was detected in Hojiblanca olives only. Benzoic acid could be formed from benzaldehyde oxidation. Apparently, the rate of oxidation of benzaldehyde to benzoic acid was higher in Hojiblanca (which contained 35\% 
benzaldehyde) than in Manzanilla (16\% benzaldehyde), indicating first order dependence with substrate.

Another volatile that was formed (Hojiblanca) or increased significantly (Manzanilla) with packing, presumably due to the sterilization treatment, was dimethyl sulfide. This compound may be produced from the thermal degradation of $S$-methylmethionine (Cerny, 2015). However, references reporting the presence of this non-proteinogenic amino acid in olives have not been found.

3.5. Volatile compounds in olives after storage

The storage of black ripe olives for 8 months did not significantly change (Manzanilla) or slightly increased (Hojiblanca) the total peak area of headspace volatile compounds (Figure 1). Carbonyl compounds, which did not significantly change during storage, remained as the predominant chemical class after 8 months' storage of both cultivars (Figure 2). Regarding individual compounds, the qualitative composition of volatiles hardly varied during storage. As found after packing, the most abundant volatiles in both cultivars after storage were benzaldehyde, ethyl acetate, dimethyl sulfide, 2methylbutanal and 3-methylbutanal (Tables 1 and 2). All of these compounds remained unchanged during the storage of Manzanilla olives, except ethyl acetate which increased significantly, whereas all of them increased in Hojiblanca, except benzaldehyde which remained unchanged (Tables S1 and S2). In fact, some $49 \%$ of the volatiles identified in Manzanilla black ripe olives remained stable during storage, whereas $21 \%$ remained unchanged in Hojiblanca. Among the minor volatiles, it is worth mentioning the 
decrease in furfural, presumably due to its reduction to furfuryl alcohol, as supported by the corresponding increase in this alcohol found in Hojiblanca olives (Table S2). In addition, other aldehydes such as octanal, 2-heptenal, (E)-2-octenal, and (E)-2-decenal, which were originated mostly as a result of the sterilization treatment, were significantly decreased with the storage of both cultivars. It could be due to the reductive effect of $\mathrm{Fe}^{2+}$ (from the ferrous gluconate added), as mentioned above. It is also worth noting that acetic acid, which was not detected after packing, was found after 8 months' storage of Manzanilla olives but not Hojiblanca. This might be attributed to the acidification of olive pulp during storage, as indicated by the increasing values of titratable acidity and concomitant decreases in $\mathrm{pH}$ (Table S4), presumably due to pectin degradation. It is known that non-enzymatic $\beta$-elimination and demethoxylation reactions which occur during the storage of low-acid fruits and vegetables produce a decrease in $\mathrm{pH}$ (GarcíaGarcía, Sánchez-Gómez, \& Garrido-Fernández, 2014). As a result, the pH reached 4.9 (a value close to the $\mathrm{pK}_{\mathrm{a}}$ of acetic acid) in Manzanilla olives, which increased the concentration of the undissociated form (i.e., the volatile form) of acetic acid, but the pH remained above 6 in Hojiblanca.

\section{Conclusions}

The present study determined the impact of each step of black ripe olive processing on the volatile composition of two Spanish olive cultivars (Manzanilla and Hojiblanca). The volatiles were analyzed by means of headspace gas chromatography (HS-GC) and solid-phase microextraction (SPME) followed by gas chromatography-mass 
spectrometry (GC-MS). Among the volatile compounds identified after the preservation step, around $60 \%$ corresponded to compounds formed during this step, mostly through enzymatic and lipid oxidation reactions; whereas the remaining compounds corresponded to olive-derived compounds (i.e. initially detected in the fresh olives). Ethyl acetate, methyl acetate, and ethanol were the dominant volatiles after the preservation step (without taking into account the acetic acid added to the preservation solution). The darkening step had a noticeable impact on the headspace volatile profile of olives, with 55\% (Manzanilla) or 65\% (Hojiblanca) of the volatiles being totally or partially eliminated as a result of this step. 2-Methylbutanal, 3-methylbutanal, 3ethylpyridine, and 3-ethyl-4-methylpyridine were formed in both cultivars, and octane and benzaldehyde increased, during darkening. Around $70 \%$ of the identified constituents in the final products (i.e., packed and sterilized olives from Manzanilla or Hojiblanca cultivars) corresponded to compounds that were formed or increased significantly, likely due to different chemical reactions occurring during the sterilization treatment at $121^{\circ} \mathrm{C}$ (e.g. the Maillard reaction, oxidative degradation reactions of fatty acids and amino acids, condensation reactions of carbonyl compounds with ammonia or amino acids, and thermal degradation of other components of olives such as carotenoids and phenolic acids). Among these compounds both in Manzanilla and Hojiblanca ripe olives, the dominant headspace volatile compounds were benzaldehyde, dimethyl sulfide, and ethyl acetate. However, differences in the volatile composition and content between the two final products were found. The storage step for 8 months at room temperature had little effect on the volatile profile of black ripe olives in general, 
although the Manzanilla cultivar showed better behavior with regards to the stability of individual volatiles.

\section{Acknowledgements}

This work was supported by the Ministry of Economy and Competitiveness from the Spanish government through Project AGL2014-54048-R, partially financed by the European Regional Development Fund (ERDF).

\section{References}

ASEMESA (Asociación Española de Exportadores e Industriales de Aceitunas de Mesa). Rasgos principales del sector de la aceituna de mesa. (2019).

http://www.asemesa.es/content/datos_generales_del_sector/ Accessed 1 March 2019.

Bleve, G., Tufariello, M., Durante, M., Grieco, F., Ramires, F. A., Mita, G., ... Logrieco, A. F. (2015). Physico-chemical characterization of natural fermentation process of Conservolea and Kalamàta table olives and developement of a protocol for the pre-selection of fermentation starters. Food Microbiology, 46, 368-382. https://doi.org/10.1016/j.fm.2014.08.021

Cano-Lamadrid, M., Girón, I. F., Pleite, R., Burló, F., Corell, M., Moriana, A., \& Carbonell-Barrachina, A. A. (2015). Quality attributes of table olives as affected by regulated deficit irrigation. LWT - Food Science and Technology, 62(1), 19-26. https://doi.org/10.1016/j.lwt.2014.12.063 
Cerny, C. (2015). The role of sulfur chemistry in thermal generation of aroma. In J.K. Parker, J.S. Elmore, L. Methven (Eds.), Flavor development, analysis and perception in food and beverages (pp. 187-210). Amsterdam: Elsevier Inc.

Chu, F.L., \& Yaylayan, V. A. (2008). Model studies on the oxygen-induced formation of benzaldehyde from phenylacetaldehyde using pyrolysis GC-MS and FTIR. Journal of Agricultural and Food Chemistry, 56(22), 10697-10704.

https://doi.org/10.1021/jf8022468

Cortés-Delgado, A., Sánchez, A. H., de Castro, A., López-López, A., Beato, V. M., \& Montaño, A. (2016). Volatile profile of Spanish-style green table olives prepared from different cultivars grown at different locations. Food Research International, 83, 131142. https://doi.org/10.1016/j.foodres.2016.03.005

Cremer, D. R., \& Eichner, K. (2000). Formation of volatile compounds during heating of spice paprika (Capsicum annuum) powder. Journal of Agricultural and Food Chemistry, 48(6), 2454-2460. https://doi.org/10.1021/jf991375a

De Angelis, M., Campanella, D., Cosmai, L., Summo, C., Rizzello, C. G., \& Caponio, F. (2015). Microbiota and metabolome of un-started and started Greek-type fermentation of Bella di Cerignola table olives. Food Microbiology, 52, 18-30. https://doi.org/10.1016/j.fm.2015.06.002

de Castro, A., García, P., Romero, C., Brenes, M., \& Garrido, A. (2007). Industrial implementation of black ripe olive storage under acid conditions. Journal of Food Engineering, 80(4), 1206-1212. https://doi.org/10.1016/j.jfoodeng.2006.09.010 de Castro, A., Sánchez, A. H., Cortés-Delgado, A., López-López, A., \& Montaño, A. (2019). Effect of Spanish-style processing steps and inoculation with Lactobacillus 
pentosus starter culture on the volatile composition of cv. Manzanilla green olives. Food Chemistry, 271, 543-549. https://doi.org/10.1016/j.foodchem.2018.07.166 de Castro, A., Sánchez, A. H., López-López, A., Cortés-Delgado, A., Medina, E., \& Montaño, A. (2018). Microbiota and metabolite profiling of spoiled spanish-style green table olives. Metabolites, 8, 73. https://doi.org/10.3390/metabo8040073 Eshkol, N., Kashi, Y., Sendovski, M., Fishman, A., Katz-Ezov, T., \& Bahalul, M. (2009). Production of 2-phenylethanol from L-phenylalanine by a stress tolerant Saccharomyces cerevisiae strain . Journal of Applied Microbiology, 106(2), 534-542. https://doi.org/10.1111/j.1365-2672.2008.04023.x

Fiddler, W., Parker, W. E., Wasserman, A. E., \& Doerr, R. C. (1967). Thermal decomposition of ferulic acid. Journal of Agricultural and Food Chemistry, 15(5), 757761. https://doi.org/10.1021/jf60153a003

Frankel, E. N. (1983). Volatile lipid oxidation products. Progress in Lipid Research, 22(1), 1-33. https://doi.org/10.1016/0163-7827(83)90002-4

García-García, P., Sánchez-Gómez, A. H., \& Garrido-Fernández, A. (2014). Changes of physicochemical and sensory characteristics of packed ripe table olives from Spanish cultivars during shelf-life. International Journal of Food Science and Technology, 49(3), 895-903. https://doi.org/10.1111/ijfs.12383 International Olive Oil Council, IOOC (2004). Trade standard applying to table olives. COI/OT/NC no. 1. Resolution no. RES-2/91-IV/04. Madrid: IOOC.

Lee, S. M., Kitsawad, K., Sigal, A., Flynn, D., \& Guinard, J. X. (2012). Sensory properties and consumer acceptance of imported and domestic sliced black ripe olives. Journal of Food Science, 77(12), S438-SS448. https://doi.org/10.1111/j.1750- 
3841.2012.03001.x

López-López, A., Rodríguez-Gómez, F., Cortés-Delgado, A., Montano, A., \& GarridoFernández, A. (2009). Influence of ripe table olive processing on oil characteristics and composition as determined by chemometrlcs. Journal of Agricultural and Food Chemistry, 57(19), 8973-8981. https://doi.org/10.1021/jf901488h

López-López, A., Sánchez, A. H., Montaño, A., Cortés-Delgado, A., \& GarridoFernández, A. (2019). Sensory characterisation of black ripe table olives from Spanish Manzanilla and Hojiblanca cultivars. Food Research International, 116, 114-125. https://doi.org/10.1016/j.foodres.2018.12.057

López-López, A., Sánchez, A. H., Cortés-Delgado, A., de Castro, A., \& Montaño, A. (2018). Relating sensory analysis with SPME-GC-MS data for Spanish-style green table olive aroma profiling. LWT - Food Science and Technology, 89, 725-734. https://doi.org/10.1016/j.lwt.2017.11.058

Malheiro, R., de Pinho, P. G., Casal, S., Bento, A., \& Pereira, J. A. (2011).

Determination of the volatile profile of stoned table olives from different varieties by using HS-SPME and GC/IT-MS. Journal of the Science of Food and Agriculture, 91(9), 1693-1701. https://doi.org/10.1002/jsfa.4372

Mamlouk, D., \& Gullo, M. (2013). Acetic acid bacteria: physiology and carbon sources oxidation. Indian Journal of Microbiology, 53(4), 377-384.

https://doi.org/10.1007/s12088-013-0414-Z

Marsilio, V., Campestre, C., \& Lanza, B. (2001). Phenolic compounds change during California-style ripe olive processing. Food Chemistry, 74(1), 55-60. https://doi.org/10.1016/S0308-8146(00)00338-1 
Martins, S.I.F.S., Jongen, W.M.F., \& van Boekel, M.A.J.S. (2001). A review of Maillard reaction in food and implications to kinetic modelling. Trends in Food Science and Technology, 11, 364-373.

Martorana, A., Alfonzo, A., Gaglio, R., Settanni, L., Corona, O., La Croce, F., ...

Francesca, N. (2017). Evaluation of different conditions to enhance the performances of Lactobacillus pentosus OM13 during industrial production of Spanish-style table olives. Food Microbiology, 61, 150-158. https://doi.org/10.1016/j.fm.2016.08.007

Navarro, T., De Lorenzo, C., \& Pérez, R. A. (2004). SPME analysis of volatile compounds from unfermented olives subjected to thermal treatment. Analytical and Bioanalytical Chemistry, 379(5-6), 812-817. https://doi.org/10.1007/s00216-004-2552$\mathrm{y}$

Nierop Groot MN, \& de Bont JAM. (1998). Conversion of phenylalanine to benzaldehyde initiated by an aminotransferase in Lactobacillus plantarum. Applied and Environmental Microbiology, 64(8), 3009-3013.

Ramírez, E., Medina, E., García, P., Brenes, M., \& Romero, C. (2017). Optimization of the natural debittering of table olives. LWT - Food Science and Technology, 77, 308313. https://doi.org/10.1016/j.lwt.2016.11.071

Randazzo, C. L., Todaro, A., Pino, A., Pitino, I., Corona, O., \& Caggia, C. (2017). Microbiota and metabolome during controlled and spontaneous fermentation of Nocellara Etnea table olives. Food Microbiology, 65, 136-148. https://doi.org/10.1016/j.fm.2017.01.022 Reyes-Garcés, N., Gionfriddo, E., Gómez-Rios, G.A., Alam, M.N., Boyaci, E., Bojko, B., ...Pawliszyn, J. (2018). Advances in solid phase microextraction and perspective on 
future directions. Analytical Chemistry, 90, 302-360.

https://doi.org/10.1021/acs.analchem.7b04502.

Ridolfi, M., Terenziani, S., Patumi, M., \& Fontanazza, G. (2002). Characterization of the lipoxygenases in some olive cultivars and determination of their role in volatile compounds formation. Journal of Agricultural and Food Chemistry, 50(4), 835-839. https://doi.org/10.1021/jf0109118

Rizzi, G. P. (2006). Formation of strecker aldehydes from polyphenol-derived quinones and $\alpha$-amino acids in a nonenzymic model system. Journal of Agricultural and Food Chemistry, 54(5), 1893-1897. https://doi.org/10.1021/jf052781z

Sabatini, N., \& Marsilio, V. (2008). Volatile compounds in table olives (Olea Europaea L., Nocellara del Belice cultivar). Food Chemistry, 107(4), 1522-1528. https://doi.org/10.1016/j.foodchem.2007.10.008

Sánchez, A. H., de Castro, A., López-López, A., Cortés-Delgado, A., Beato, V. M., \& Montaño, A. (2017). Retention of color and volatile compounds of Spanish-style green table olives pasteurized and stored in plastic containers under conditions of constant temperature. LWT - Food Science and Technology, 75, 685-691. https://doi.org/10.1016/j.lwt.2016.10.027 Sánchez, A. H., López-López, A., Cortés-Delgado, A., Beato, V. M., Medina, E., de Castro, A., \& Montaño, A. (2018). Effect of post-fermentation and packing stages on the volatile composition of Spanish-style green table olives. Food Chemistry, 239, 343353. https://doi.org/10.1016/j.foodchem.2017.06.125

Sánchez Gómez, A. H., García García, P., \& Rejano Navarro, L. (2006). Trends in table olive production: Elaboration of table olives. Grasas y Aceites, 57(1), 86-94. 
https://doi.org/10.3989/gya.2006.v57.i1.24

Sansone-Land, A., Takeoka, G. R., \& Shoemaker, C. F. (2014). Volatile constituents of commercial imported and domestic black-ripe table olives (Olea europaea). Food Chemistry, 149, 285-295. https://doi.org/10.1016/j.foodchem.2013.10.090

Selli, S., Kelebek, H., Kesen, S., \& Sonmezdag, A. S. (2018). GC-MS olfactometric and LC-DAD-ESI-MS/MS characterization of key odorants and phenolic compounds in black dry-salted olives. Journal of the Science of Food and Agriculture, 98(11), 41044111. https://doi.org/10.1002/jsfa.8927

Suyama, K., \& Adachi, S. (1980). Origin of alkyl-substituted pyridines in food flavor: formation of the pyridines from the reaction of alkanals with amino acids. Journal of Agricultural and Food Chemistry, 28(3), 546-549. https://doi.org/10.1021/jf60229a048 Tzika, E. D., Sotiroudis, T. G., Papadimitriou, V., \& Xenakis, A. (2009). Partial purification and characterization of peroxidase from olives (Olea europaea cv. Koroneiki). European Food Research and Technology, 228(3), 487-495. https://doi.org/10.1007/s00217-008-0956-1 Zamora, R., Navarro, J. L., Gallardo, E., \& Hidalgo, F. J. (2006). Chemical conversion of $\alpha$-amino acids into $\alpha$-keto acids by 4,5-epoxy-2-decenal. Journal of Agricultural and Food Chemistry, 54(16), 6101-6105. https://doi.org/10.1021/jf061239n

\section{Figure captions}


Fig.1. Total peak area of headspace volatile compounds during processing and storage of black ripe olives from Manzanilla and Hojiblanca cultivars. Error bars indicate 95\% confidence intervals. Peak area of acetic acid after preservation step was not considered.

Fig. 2. Changes in chemical classes of the headspace volatile compounds during processing and storage of black ripe olives from Manzanilla and Hojiblanca cultivars. Error bars indicate $95 \%$ confidence intervals. For clarity, acids were not included.

\section{Supplementary material}

Table S1: Volatile compounds identified and changes in their peak areas during processing and storage of black ripe olives (Manzanilla cultivar)

Table S2: Volatile compounds identified and changes in their peak areas during processing and storage of black ripe olives (Hojiblanca cultivar)

Table S3: Physico-chemical and microbiological characteristics of the preservation liquid of olives (Manzanilla and Hojiblanca cultivars) after 3 months of preservation

Table S4: Changes in physico-chemical characteristics of packing brines from Manzanilla and Hojiblanca ripe olives due to storage time 
Table 1. Relative contents of volatile compounds during processing and storage of black ripe olives (Manzanilla cultivar)

\begin{tabular}{|c|c|c|c|c|c|}
\hline & Content $(\%$ & otal area of ide & fified compou & & \\
\hline Compound & Fresh fruit $^{\mathrm{a}}$ & $\begin{array}{l}\text { After } \\
\text { preservation }^{\text {a }}\end{array}$ & $\begin{array}{l}\text { After } \\
\text { darkening }^{\mathrm{a}}\end{array}$ & $\begin{array}{l}\text { After } \\
\text { packing }^{\mathrm{b}}\end{array}$ & After storage $^{b}$ \\
\hline Acetic acid & n.d. & $58 \pm 3$ & n.d. & n.d. & $0.9 \pm 0.2$ \\
\hline Ethanol & n.d. & $6.8 \pm 0.1$ & $3.2 \pm 0.2$ & $1.0 \pm 0.1$ & $0.74 \pm 0.06$ \\
\hline 1-Penten-3-ol & $14 \pm 1$ & n.d. & n.d. & n.d. & n.d. \\
\hline Isopentanol & n.d. & $0.14 \pm 0.01$ & n.d. & n.d. & n.d. \\
\hline (Z)-2-Penten-1-ol & $4.9 \pm 0.4$ & n.d. & n.d. & n.d. & n.d. \\
\hline 1-Hexanol & $0.88 \pm 0.03$ & $0.098 \pm 0.006$ & $0.55 \pm 0.07$ & $0.15 \pm 0.02$ & $0.13 \pm 0.01$ \\
\hline (Z)-3-Hexen-1-ol & $17.8 \pm 0.2$ & $0.19 \pm 0.02$ & $0.74 \pm 0.07$ & $0.18 \pm 0.02$ & $0.15 \pm 0.02$ \\
\hline 1-Heptanol & n.d. & n.d. & n.d. & $0.07 \pm 0.02$ & $0.08 \pm 0.03$ \\
\hline 1-Octanol & n.d. & $0.020 \pm 0.003$ & $0.28 \pm 0.05$ & $0.12 \pm 0.02$ & $0.10 \pm 0.01$ \\
\hline Benzyl alcohol & n.d. & $0.021 \pm 0.003$ & $0.17 \pm 0.02$ & $0.051 \pm 0.008$ & $0.060 \pm 0.006$ \\
\hline Phenylethyl alcohol & $0.36 \pm 0.09$ & $0.13 \pm 0.01$ & $0.38 \pm 0.08$ & $0.13 \pm 0.04$ & $0.15 \pm 0.01$ \\
\hline 2-Methylpropanal & n.d. & n.d. & n.d. & $0.8 \pm 0.1$ & $0.9 \pm 0.1$ \\
\hline 2-Methylbutanal & n.d. & n.d. & $10 \pm 1$ & $5.4 \pm 0.4$ & $6.2 \pm 0.5$ \\
\hline 3-Methylbutanal & n.d. & n.d. & $10.1 \pm 0.7$ & $8.2 \pm 0.5$ & $9.5 \pm 0.6$ \\
\hline Pentanal & n.d. & n.d. & n.d. & $1.0 \pm 0.1$ & $1.2 \pm 0.2$ \\
\hline 3-Pentanone & $2.5 \pm 0.6$ & n.d. & n.d. & n.d. & n.d. \\
\hline 1-Penten-3-one & $9.8 \pm 0.5$ & n.d. & n.d. & n.d. & n.d. \\
\hline
\end{tabular}




\begin{tabular}{|c|c|c|c|c|c|}
\hline 2-Butenal & n.d. & n.d. & n.d. & $3.2 \pm 0.8$ & $1.1 \pm 0.2$ \\
\hline Hexanal & $0.43 \pm 0.04$ & $0.04 \pm 0.02$ & $0.22 \pm 0.03$ & $0.14 \pm 0.03$ & $0.17 \pm 0.02$ \\
\hline (E)-2-Pentenal & $2.8 \pm 0.3$ & n.d. & n.d. & n.d. & n.d. \\
\hline 3-Hexenal & $16.1 \pm 0.8$ & n.d. & n.d. & n.d. & n.d. \\
\hline 2-Ethyl-2-butenal & n.d. & n.d. & n.d. & $0.70 \pm 0.05$ & $0.72 \pm 0.09$ \\
\hline Heptanal & n.d. & $0.06 \pm 0.01$ & $0.25 \pm 0.02$ & $0.14 \pm 0.03$ & $0.14 \pm 0.02$ \\
\hline (E)-2-Hexenal & $16 \pm 1$ & n.d. & n.d. & n.d. & n.d. \\
\hline 2-Vinyl-2-butenal & n.d. & n.d. & n.d. & $8.8 \pm 0.9$ & $1.05 \pm 0.08$ \\
\hline Octanal & n.d. & $0.05 \pm 0.03$ & $0.5 \pm 0.1$ & $0.36 \pm 0.01$ & $0.21 \pm 0.05$ \\
\hline 2-Heptenal & n.d. & n.d. & $0.82 \pm 0.08$ & $0.9 \pm 0.1$ & $0.43 \pm 0.06$ \\
\hline Nonanal & n.d. & $0.04 \pm 0.02$ & $0.4 \pm 0.1$ & $0.17 \pm 0.03$ & $0.15 \pm 0.03$ \\
\hline$(E, E)-2,4-H e x a d i e n a l$ & $4.1 \pm 0.6$ & n.d. & n.d. & n.d. & n.d. \\
\hline (E)-2-Octenal & n.d. & $0.04 \pm 0.01$ & $0.32 \pm 0.03$ & $0.18 \pm 0.02$ & $0.11 \pm 0.02$ \\
\hline$(E, E)-2,4-H e p t a d i e n a l$ & n.d. & n.d. & n.d. & $0.28 \pm 0.03$ & $0.11 \pm 0.02$ \\
\hline Benzaldehyde & $0.25 \pm 0.09$ & $0.07 \pm 0.01$ & $1.8 \pm 0.2$ & $16 \pm 1$ & $16 \pm 2$ \\
\hline Phenylacetaldehyde & $2.1 \pm 0.4$ & $0.35 \pm 0.04$ & $1.9 \pm 0.2$ & $3.0 \pm 0.5$ & $1.1 \pm 0.4$ \\
\hline (E)-2-Decenal & n.d. & $0.19 \pm 0.02$ & $2.0 \pm 0.2$ & $0.90 \pm 0.09$ & $0.6 \pm 0.1$ \\
\hline 4-Ethylbenzaldehyde & n.d. & n.d. & n.d. & $0.07 \pm 0.01$ & $0.06 \pm 0.01$ \\
\hline 2-Cyclohexene-1,4-dione & $0.7 \pm 0.1$ & n.d. & n.d. & n.d. & n.d. \\
\hline$(E, E)-2,4$-Decadienal & n.d. & n.d. & n.d. & $0.13 \pm 0.02$ & $0.11 \pm 0.02$ \\
\hline (E)-Cinnamaldehyde & n.d. & n.d. & n.d. & $0.06 \pm 0.01$ & $0.06 \pm 0.02$ \\
\hline 2-Phenyl-2-butenal & n.d. & n.d. & n.d. & n.d. & $0.06 \pm 0.01$ \\
\hline Methyl acetate & n.d. & $4.3 \pm 0.4$ & n.d. & $0.9 \pm 0.2$ & $1.5 \pm 0.1$ \\
\hline Ethyl acetate & n.d. & $28 \pm 3$ & n.d. & $10 \pm 2$ & $16 \pm 1$ \\
\hline
\end{tabular}




\begin{tabular}{|c|c|c|c|c|c|}
\hline Methyl butanoate & $0.5 \pm 0.2$ & n.d. & n.d. & n.d. & n.d. \\
\hline Hexyl acetate & n.d. & $0.024 \pm 0.001$ & $0.39 \pm 0.05$ & n.d. & n.d. \\
\hline (Z)-3-Hexenyl acetate & $1.97 \pm 0.09$ & $0.45 \pm 0.02$ & $3.2 \pm 0.4$ & $0.8 \pm 0.1$ & $0.53 \pm 0.05$ \\
\hline Methyl nicotinate & n.d. & n.d. & n.d. & $0.27 \pm 0.04$ & $0.24 \pm 0.04$ \\
\hline Methyl salicylate & $0.20 \pm 0.06$ & $0.018 \pm 0.003$ & n.d. & n.d. & n.d. \\
\hline Methyl 2-formylbenzoate & n.d. & n.d. & n.d. & $1.12 \pm 0.09$ & $0.8 \pm 0.2$ \\
\hline 3-Ethylpyridine & n.d. & n.d. & $1.4 \pm 0.2$ & $1.3 \pm 0.2$ & $0.58 \pm 0.09$ \\
\hline Furfural & n.d. & n.d. & n.d. & $1.5 \pm 0.2$ & $1.0 \pm 0.1$ \\
\hline 3-Vinylpyridine & n.d. & n.d. & n.d. & $2.6 \pm 0.3$ & $1.6 \pm 0.2$ \\
\hline 3-Ethyl-4-methylpyridine & n.d. & n.d. & $0.41 \pm 0.07$ & $0.55 \pm 0.07$ & $0.28 \pm 0.06$ \\
\hline Octane & n.d. & $0.58 \pm 0.05$ & $56.0 \pm 0.3$ & $10 \pm 2$ & $17 \pm 4$ \\
\hline Toluene & n.d. & $0.05 \pm 0.01$ & $1.7 \pm 0.2$ & $0.4 \pm 0.1$ & $0.5 \pm 0.1$ \\
\hline p-Xylene & n.d. & $0.03 \pm 0.01$ & $0.8 \pm 0.1$ & $0.20 \pm 0.04$ & $0.25 \pm 0.05$ \\
\hline o-Xylene & n.d. & $0.016 \pm 0.003$ & $0.49 \pm 0.07$ & $0.14 \pm 0.04$ & $0.12 \pm 0.02$ \\
\hline Phenol & $1.6 \pm 0.2$ & $0.048 \pm 0.008$ & $0.40 \pm 0.03$ & $0.17 \pm 0.03$ & $0.18 \pm 0.02$ \\
\hline Vanillin & n.d. & n.d. & n.d. & $0.10 \pm 0.02$ & $0.33 \pm 0.07$ \\
\hline 6-Methyl-5-hepten-2-one & n.d. & n.d. & n.d. & $0.33 \pm 0.02$ & $0.19 \pm 0.05$ \\
\hline Copaene & $0.50 \pm 0.06$ & $0.043 \pm 0.002$ & $0.7 \pm 0.1$ & $0.24 \pm 0.02$ & $0.26 \pm 0.05$ \\
\hline$\beta$-Damascenone & n.d. & $0.012 \pm 0.002$ & $0.19 \pm 0.04$ & $0.06 \pm 0.01$ & $0.057 \pm 0.007$ \\
\hline Dimethyl sulfide & $3.7 \pm 0.3$ & $0.65 \pm 0.05$ & $0.73 \pm 0.09$ & $16 \pm 1$ & $16 \pm 3$ \\
\hline Dimethyl sulfoxide & n.d. & n.d. & n.d. & $0.45 \pm 0.06$ & $0.6 \pm 0.3$ \\
\hline \multicolumn{6}{|c|}{$\begin{array}{l}{ }^{\mathrm{a}} \text { Values are means } \pm \text { standard deviation }(\mathrm{n}=3) \text {. } \\
{ }^{\mathrm{b}} \text { Values are means } \pm \text { standard deviation }(\mathrm{n}=9 ; \text { three bottles analyzed in triplicate). } \\
\text { n.d. = not detected }\end{array}$} \\
\hline
\end{tabular}


Table 2. Relative contents of volatile compounds during processing and storage of black ripe olives (Hojiblanca cultivar)

\begin{tabular}{|c|c|c|c|c|c|}
\hline & \multicolumn{5}{|c|}{ Content (\% of total area of identified compounds) } \\
\hline & Fresh fruit ${ }^{\mathrm{a}}$ & $\begin{array}{l}\text { After } \\
\text { preservation }^{\text {a }}\end{array}$ & $\begin{array}{l}\text { After } \\
\text { darkening }^{\text {a }}\end{array}$ & $\begin{array}{l}\text { After } \\
\text { packing }^{b}\end{array}$ & After storage ${ }^{b}$ \\
\hline Acetic acid & n.d. & $54 \pm 5$ & n.d. & n.d. & n.d. \\
\hline Benzoic acid & n.d. & n.d. & n.d. & $0.7 \pm 0.2$ & $0.28 \pm 0.05$ \\
\hline Ethanol & n.d. & $6.9 \pm 0.7$ & n.d. & $1.7 \pm 0.4$ & $1.6 \pm 0.1$ \\
\hline 1-Penten-3-ol & $6.4 \pm 0.1$ & n.d. & n.d. & n.d. & n.d. \\
\hline Isopentanol & n.d. & $0.15 \pm 0.04$ & n.d. & n.d. & $0.11 \pm 0.02$ \\
\hline 1-Pentanol & $0.14 \pm 0.02$ & n.d. & $0.31 \pm 0.07$ & $0.08 \pm 0.01$ & $0.12 \pm 0.01$ \\
\hline (E)-2-Penten-1-ol & $0.04 \pm 0.01$ & n.d. & n.d. & n.d. & n.d. \\
\hline (Z)-2-Penten-1-ol & $2.24 \pm 0.08$ & n.d. & n.d. & n.d. & n.d. \\
\hline 1-Hexanol & $2.72 \pm 0.02$ & $0.16 \pm 0.01$ & $0.84 \pm 0.04$ & $0.10 \pm 0.01$ & $0.11 \pm 0.01$ \\
\hline (E)-3-Hexen-1-ol & $0.17 \pm 0.02$ & n.d. & n.d. & n.d. & n.d. \\
\hline (Z)-3-Hexen-1-ol & $33 \pm 1$ & $0.23 \pm 0.03$ & $1.35 \pm 0.04$ & $0.16 \pm 0.01$ & $0.11 \pm 0.01$ \\
\hline (E)-2-Hexen-1-ol & $0.14 \pm 0.02$ & n.d. & n.d. & n.d. & n.d. \\
\hline 1-Heptanol & n.d. & n.d. & n.d. & n.d. & $0.05 \pm 0.01$ \\
\hline 1-Octanol & n.d. & $0.02 \pm 0.00$ & $0.33 \pm 0.04$ & $0.09 \pm 0.01$ & $0.06 \pm 0.01$ \\
\hline Benzyl alcohol & $0.14 \pm 0.02$ & $0.05 \pm 0.00$ & $0.49 \pm 0.01$ & $0.12 \pm 0.01$ & $0.11 \pm 0.01$ \\
\hline Phenylethyl alcohol & $0.32 \pm 0.02$ & $0.17 \pm 0.01$ & $0.8 \pm 0.1$ & $0.17 \pm 0.03$ & $0.17 \pm 0.02$ \\
\hline 2-Methylpropanal & n.d. & n.d. & n.d. & $0.6 \pm 0.2$ & $0.90 \pm 0.04$ \\
\hline 2-Methylbutanal & n.d. & n.d. & $7.6 \pm 0.9$ & $3.8 \pm 0.4$ & $5.7 \pm 0.4$ \\
\hline 3-Methylbutanal & n.d. & n.d. & $12 \pm 2$ & $6.9 \pm 0.8$ & $7.9 \pm 0.9$ \\
\hline
\end{tabular}




\begin{tabular}{|c|c|c|c|c|c|}
\hline Pentanal & n.d. & n.d. & n.d. & $1.3 \pm 0.2$ & $1.3 \pm 0.3$ \\
\hline 3-Pentanone & $1.50 \pm 0.08$ & n.d. & n.d. & n.d. & n.d. \\
\hline 1-Penten-3-one & $8.9 \pm 0.3$ & n.d. & n.d. & n.d. & n.d. \\
\hline 2-Butenal & n.d. & n.d. & n.d. & $0.93 \pm 0.06$ & $1.0 \pm 0.2$ \\
\hline Hexanal & $2.1 \pm 0.2$ & $0.13 \pm 0.04$ & $0.29 \pm 0.01$ & $0.10 \pm 0.04$ & $0.08 \pm 0.01$ \\
\hline (E)-2-Pentenal & $3.6 \pm 0.2$ & n.d. & n.d. & n.d. & n.d. \\
\hline 2-Ethyl-2-butenal & n.d. & n.d. & n.d. & $0.85 \pm 0.08$ & $0.92 \pm 0.08$ \\
\hline 3-Hexenal & $12.9 \pm 0.9$ & n.d. & n.d. & n.d. & n.d. \\
\hline Heptanal & n.d. & $0.08 \pm 0.02$ & $0.50 \pm 0.00$ & $0.09 \pm 0.03$ & $0.08 \pm 0.01$ \\
\hline (E)-2-Hexenal & $16 \pm 1$ & n.d. & n.d. & n.d. & n.d. \\
\hline Octanal & n.d. & $0.07 \pm 0.00$ & $0.45 \pm 0.08$ & $0.26 \pm 0.03$ & $0.13 \pm 0.04$ \\
\hline 2-Heptenal & n.d. & n.d. & n.d. & $0.6 \pm 0.1$ & $0.3 \pm 0.2$ \\
\hline Nonanal & n.d. & $0.07 \pm 0.02$ & $1.6 \pm 0.4$ & $0.17 \pm 0.04$ & $0.11 \pm 0.01$ \\
\hline$(E, E)-2,4-H e x a d i e n a l$ & $3.1 \pm 0.3$ & n.d. & n.d. & n.d. & n.d. \\
\hline (E)-2-Octenal & n.d. & n.d. & n.d. & $0.10 \pm 0.01$ & $0.03 \pm 0.01$ \\
\hline$(E, E)-2,4$-Heptadienal & $0.29 \pm 0.04$ & n.d. & n.d. & $0.34 \pm 0.05$ & n.d. \\
\hline Benzaldehyde & $0.23 \pm 0.02$ & $0.12 \pm 0.02$ & $3.0 \pm 0.4$ & $36 \pm 2$ & $30 \pm 2$ \\
\hline Phenylacetaldehyde & $0.9 \pm 0.1$ & $0.79 \pm 0.03$ & n.d. & n.d. & n.d. \\
\hline (E)-2-Decenal & n.d. & n.d. & n.d. & $0.36 \pm 0.06$ & $0.12 \pm 0.04$ \\
\hline 4-Ethylbenzaldehyde & n.d. & n.d. & n.d. & $0.32 \pm 0.04$ & $0.21 \pm 0.02$ \\
\hline 2-Cyclohexene-1,4-dione & $0.50 \pm 0.03$ & n.d. & n.d. & n.d. & n.d. \\
\hline$(E, E)$-2,4-Decadienal & n.d. & n.d. & n.d. & $0.27 \pm 0.05$ & $0.12 \pm 0.02$ \\
\hline (E)-Cinnamaldehyde & n.d. & n.d. & n.d. & $0.24 \pm 0.07$ & $0.12 \pm 0.01$ \\
\hline 2-Phenyl-2-butenal & n.d. & n.d. & n.d. & n.d. & $0.15 \pm 0.02$ \\
\hline
\end{tabular}




\begin{tabular}{|l|l|l|l|l|l|}
\hline Methyl acetate & n.d. & $3.9 \pm 0.7$ & n.d. & $1.2 \pm 0.3$ & $1.7 \pm 0.1$ \\
\hline Ethyl acetate & n.d. & $29 \pm 4$ & n.d. & $12 \pm 2$ & $18.0 \pm 0.7$ \\
\hline Methyl butanoate & $0.16 \pm 0.01$ & n.d. & n.d. & n.d. & n.d. \\
\hline Hexyl acetate & n.d. & $0.07 \pm 0.01$ & $0.85 \pm 0.09$ & $0.08 \pm 0.02$ & $0.06 \pm 0.01$ \\
\hline Z)-3-Hexenyl acetate & $1.0 \pm 0.1$ & $1.26 \pm 0.08$ & $5.6 \pm 0.1$ & $0.57 \pm 0.09$ & $0.48 \pm 0.04$ \\
\hline Methyl nicotinate & n.d. & n.d. & n.d. & $0.11 \pm 0.02$ & $0.08 \pm 0.02$ \\
\hline Methyl salicylate & $0.33 \pm 0.02$ & $0.06 \pm 0.01$ & $0.19 \pm 0.04$ & n.d. & n.d. \\
\hline Ethyl salicylate & n.d. & $0.08 \pm 0.01$ & $0.50 \pm 0.03$ & n.d. & n.d. \\
\hline Methyl 2-formylbenzoate & n.d. & n.d. & n.d. & $0.54 \pm 0.04$ & $0.16 \pm 0.03$ \\
\hline Pyridine & n.d. & n.d. & n.d. & $0.57 \pm 0.07$ & $0.54 \pm 0.07$ \\
\hline 3-Methylpyridine & n.d. & n.d. & n.d. & $1.5 \pm 0.2$ & $2.1 \pm 0.3$ \\
\hline 3-Ethylpyridine & n.d. & n.d. & $2.85 \pm 0.08$ & $2.6 \pm 0.3$ & $1.6 \pm 0.2$ \\
\hline Furfural & n.d. & n.d. & n.d. & $1.6 \pm 0.2$ & $0.62 \pm 0.05$ \\
\hline 3-Vinylpyridine & n.d. & n.d. & n.d. & $4.2 \pm 0.6$ & $2.9 \pm 0.4$ \\
\hline 3-Ethyl-4-methylpyridine & n.d. & n.d. & $1.1 \pm 0.1$ & $1.8 \pm 0.2$ & $1.3 \pm 0.2$ \\
\hline Furfuryl alcohol & n.d. & n.d. & n.d. & $0.09 \pm 0.02$ & $0.12 \pm 0.01$ \\
\hline Octane & n.d. & $0.15 \pm 0.01$ & $15.4 \pm 0.3$ & $0.80 \pm 0.09$ & $2.0 \pm 0.6$ \\
\hline Toluene & n.d. & $1.66 \pm 0.09$ & $12.0 \pm 0.9$ & $0.6 \pm 0.1$ & $0.27 \pm 0.07$ \\
\hline$p$-Xylene & n.d. & $0.97 \pm 0.02$ & $8.3 \pm 0.4$ & $0.5 \pm 0.1$ & $0.6 \pm 0.2$ \\
\hline$o$-Xylene & $0.18 \pm 0.01$ & $0.27 \pm 0.01$ & $2.9 \pm 0.1$ & $0.25 \pm 0.06$ & $0.24 \pm 0.04$ \\
\hline Styrene & $0.54 \pm 0.04$ & $4.5 \pm 0.3$ & $0.32 \pm 0.08$ & $0.37 \pm 0.04$ \\
\hline Pseudocumene & $0.03 \pm 0.01$ & n.d. & n.d. & n.d. \\
\hline$p$-Creosol & $0.09 \pm 0.02$ & $1.2 \pm 0.2$ & $0.38 \pm 0.05$ & $0.16 \pm 0.01$ \\
\hline Phenol & $0.13 \pm 0.02$ & $2.5 \pm 0.2$ & $0.19 \pm 0.05$ & $0.3 \pm 0.1$ \\
\hline
\end{tabular}




\begin{tabular}{|c|c|c|c|c|c|}
\hline Vanillin & n.d. & n.d. & n.d. & $0.12 \pm 0.01$ & $0.18 \pm 0.03$ \\
\hline 6-Methyl-5-hepten-2-one & n.d. & n.d. & n.d. & $0.27 \pm 0.04$ & $0.15 \pm 0.07$ \\
\hline Copaene & $0.28 \pm 0.05$ & $0.24 \pm 0.04$ & $3.1 \pm 0.9$ & $0.9 \pm 0.2$ & $0.57 \pm 0.06$ \\
\hline$\alpha$-Muurolene & n.d. & $0.01 \pm 0.00$ & $0.24 \pm 0.08$ & $0.08 \pm 0.02$ & $0.04 \pm 0.01$ \\
\hline$\beta$-Damascenone & n.d. & $0.07 \pm 0.02$ & $1.2 \pm 0.1$ & $0.17 \pm 0.04$ & $0.13 \pm 0.02$ \\
\hline Dimethyl sulfide & $1.1 \pm 0.1$ & $0.08 \pm 0.02$ & n.d. & $11 \pm 2$ & $13 \pm 1$ \\
\hline Dimethyl sulfoxide & n.d. & n.d. & n.d. & $0.6 \pm 0.2$ & $0.38 \pm 0.05$ \\
\hline (Z)-3-Hexenyl methyl ether & $0.91 \pm 0.08$ & $0.47 \pm 0.03$ & $7.5 \pm 0.1$ & $0.36 \pm 0.06$ & $0.47 \pm 0.08$ \\
\hline Benzyl methyl ether & n.d. & $0.17 \pm 0.01$ & $1.5 \pm 0.1$ & $0.14 \pm 0.02$ & $0.11 \pm 0.01$ \\
\hline \multicolumn{6}{|c|}{$\begin{array}{l}{ }^{\mathrm{a}} \text { Values are means } \pm \text { standard deviation }(\mathrm{n}=3) \\
{ }^{\mathrm{b}} \text { Values are means } \pm \text { standard deviation }(\mathrm{n}=9 ; \text { three bottles analyzed in triplicate). } \\
\text { n.d. = not detected }\end{array}$} \\
\hline
\end{tabular}



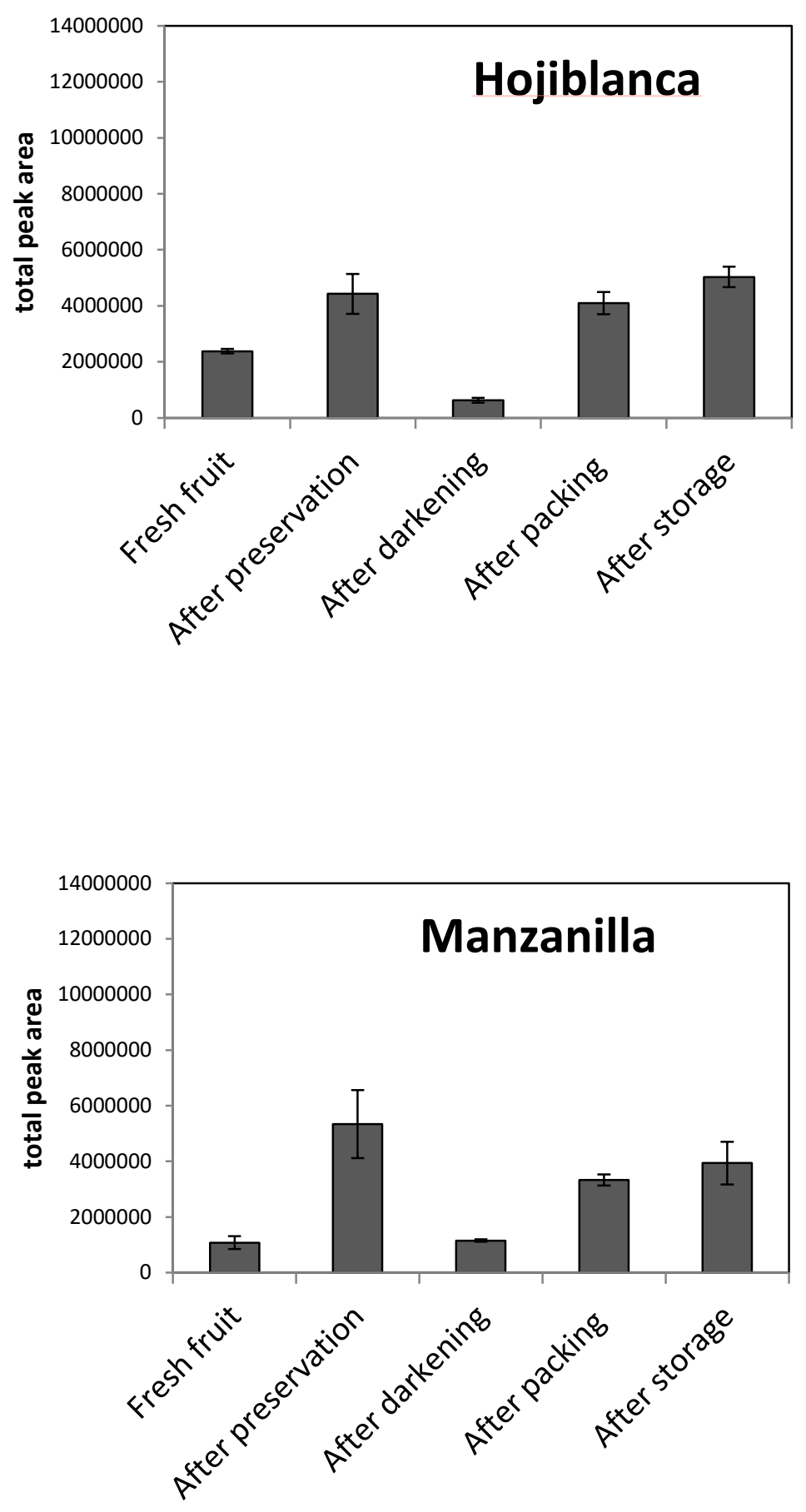

Figure 1 

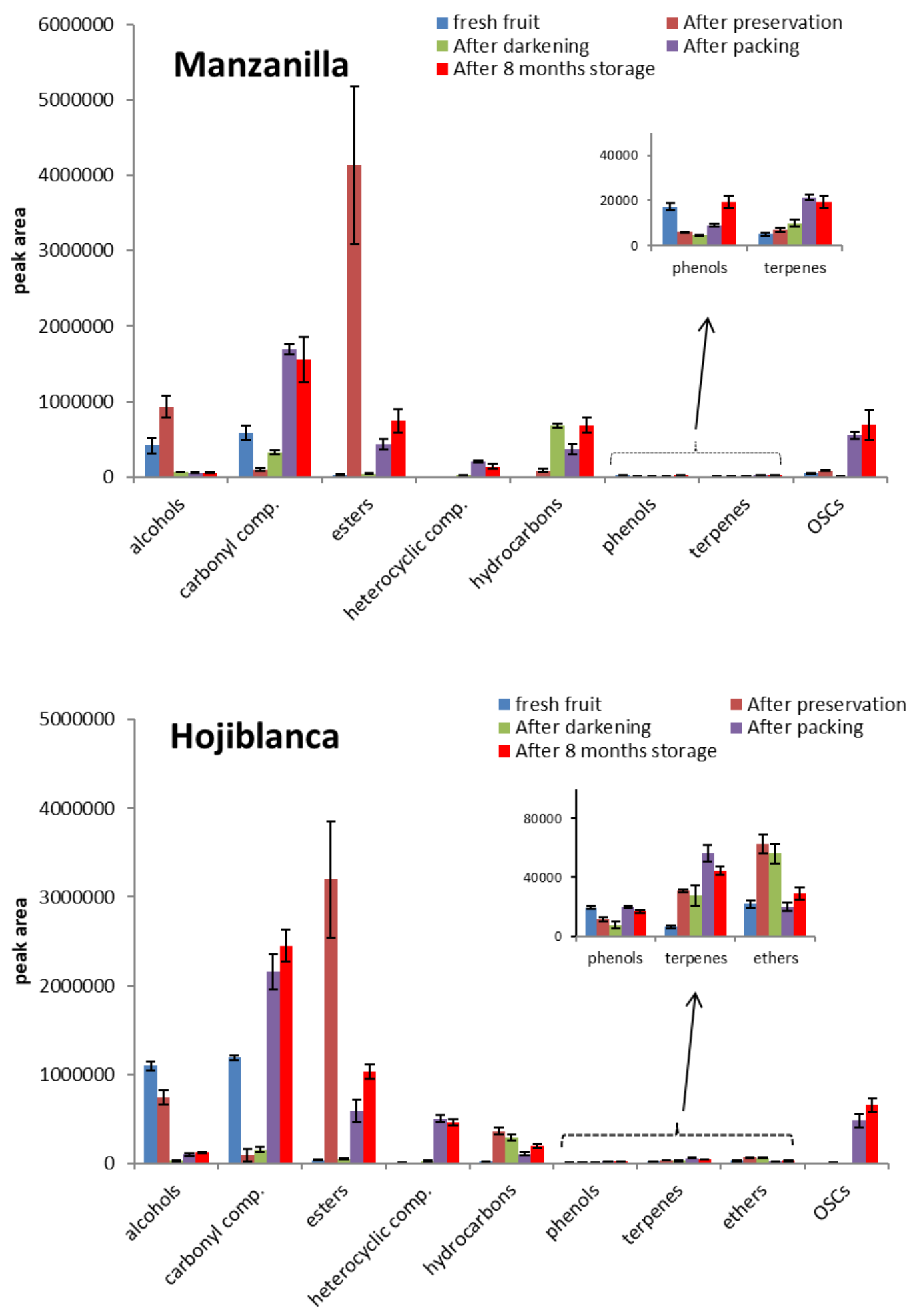

Figure 2 


\begin{tabular}{|c|c|c|c|c|c|c|c|c|c|c|c|c|}
\hline \multirow[b]{2}{*}{ Compound } & \multirow[b]{2}{*}{$\begin{array}{l}\text { IEC } \\
(m / z)^{\mathrm{a}}\end{array}$} & \multirow[b]{2}{*}{$\mathrm{ID}^{\mathrm{b}}$} & \multicolumn{2}{|c|}{ Fresh fruit } & \multicolumn{2}{|c|}{ After preservation } & \multicolumn{2}{|c|}{ After darkening } & \multicolumn{2}{|c|}{ After packing } & \multicolumn{2}{|c|}{ After storage } \\
\hline & & & $\begin{array}{l}\text { Average } \\
\text { area }\end{array}$ & $\mathrm{SD}^{\mathrm{c}}$ & $\begin{array}{l}\text { Average } \\
\text { area }\end{array}$ & $\mathrm{SD}^{\mathrm{c}}$ & $\begin{array}{l}\text { Average } \\
\text { area }\end{array}$ & $\mathrm{SD}^{\mathrm{c}}$ & $\begin{array}{l}\text { Average } \\
\text { area }\end{array}$ & $\mathrm{SD}^{\mathrm{d}}$ & $\begin{array}{l}\text { Average } \\
\text { area }\end{array}$ & $\mathrm{SD}^{\mathrm{d}}$ \\
\hline acetic acid & 60 & 1 & n.d. & & $\begin{array}{l}7272375^{\mathrm{e}} \\
(\mathbf{F})\end{array}$ & 783368 & $\begin{array}{l}\text { n.d. } \\
(\mathbf{E})\end{array}$ & & n.d. & & $\begin{array}{l}42537 \\
(\mathbf{F})\end{array}$ & 19819 \\
\hline ethanol & 45 & 1 & n.d. & & $\begin{array}{l}851478 \\
(\mathbf{F})\end{array}$ & 115348 & $\begin{array}{l}36333 \\
(\downarrow \mathbf{2 3 . 4})\end{array}$ & 3374 & $\begin{array}{l}33681 \\
\text { (n.s.) }\end{array}$ & 2824 & $\begin{array}{l}29523 \\
\text { (n.s.) }\end{array}$ & 9570 \\
\hline 1-penten-3-ol* & 57 & 1 & 153537 & 39812 & $\begin{array}{l}\text { n.d. } \\
\text { (E) }\end{array}$ & & n.d. & & n.d. & & n.d. & \\
\hline isopentanol & 55 & 1 & n.d. & & $\begin{array}{l}17491 \\
\text { (F) }\end{array}$ & 4017 & $\begin{array}{l}\text { n.d. } \\
\text { (E) }\end{array}$ & & n.d. & & n.d. & \\
\hline (Z)-2-penten-1-ol* & 68 & 2 & 53461 & 13305 & $\begin{array}{l}\text { n.d. } \\
\text { (E) }\end{array}$ & & n.d. & & n.d. & & n.d. & \\
\hline 1-hexanol** & 56 & 1 & 9618 & 1920 & $\begin{array}{l}12358 \\
\text { (n.s.) }\end{array}$ & 2154 & $\begin{array}{l}6310 \\
(\downarrow \mathbf{2 . 0}) \\
\end{array}$ & 670 & $\begin{array}{l}4946 \\
(\downarrow \mathbf{1 . 3}) \\
\end{array}$ & 500 & $\begin{array}{l}5193 \\
\text { (n.s.) }\end{array}$ & 1830 \\
\hline (Z)-3-hexen-1-ol* & 67 & 1 & 193558 & 35757 & $\begin{array}{l}23908 \\
(\downarrow \mathbf{8 . 1}) \\
\end{array}$ & 4451 & $\begin{array}{l}8554 \\
(\downarrow \mathbf{2 . 8}) \\
\end{array}$ & 615 & $\begin{array}{l}5960 \\
(\downarrow 1.4) \\
\end{array}$ & 648 & $\begin{array}{l}6171 \\
\text { (n.s.) }\end{array}$ & 2469 \\
\hline 1-heptanol & 70 & 1 & n.d. & & n.d. & & n.d. & & $\begin{array}{l}2298 \\
(\mathbf{F})\end{array}$ & 475 & $\begin{array}{l}3177 \\
(\uparrow \mathbf{1 . 4})\end{array}$ & 796 \\
\hline 1-octanol & 84 & 1 & n.d. & & $\begin{array}{l}2588 \\
(\mathbf{F})\end{array}$ & 656 & $\begin{array}{l}3257 \\
\text { (n.s.) }\end{array}$ & 474 & $\begin{array}{l}3976 \\
\text { (n.s.) }\end{array}$ & 652 & $\begin{array}{l}3720 \\
\text { (n.s.) }\end{array}$ & 937 \\
\hline benzyl alcohol & 108 & 1 & n.d. & & $\begin{array}{l}2616 \\
(\mathbf{F}) \\
\end{array}$ & 166 & $\begin{array}{l}1951 \\
(\downarrow \mathbf{1 . 3}) \\
\end{array}$ & 260 & $\begin{array}{l}1690 \\
\text { (n.s.) } \\
\end{array}$ & 275 & $\begin{array}{l}2405 \\
\text { (n.s.) } \\
\end{array}$ & 893 \\
\hline phenylethyl alcohol & 91 & 1 & 3832 & 512 & $\begin{array}{l}16120 \\
(\uparrow 4.2) \\
\end{array}$ & 835 & $\begin{array}{l}4370 \\
(\downarrow 3.7)\end{array}$ & 834 & $\begin{array}{l}4397 \\
\text { (n.s.) }\end{array}$ & 1170 & $\begin{array}{l}5805 \\
\text { (n.s.) } \\
\end{array}$ & 2047 \\
\hline 2-methylpropanal & 72 & 2 & n.d. & & n.d. & & n.d. & & $\begin{array}{l}26994 \\
(\mathbf{F})\end{array}$ & 4937 & $\begin{array}{l}35104 \\
\text { (n.s.) }\end{array}$ & 15310 \\
\hline 2-methylbutanal & 57 & 1 & n.d. & & n.d. & & $\begin{array}{l}114628 \\
(\mathbf{F})\end{array}$ & 19674 & $\begin{array}{l}180914 \\
(\uparrow \mathbf{1 . 6})\end{array}$ & 25412 & $\begin{array}{l}248270 \\
\text { (n.s.) }\end{array}$ & 92275 \\
\hline 3-methylbutanal & 44 & 2 & n.d. & & n.d. & & 117381 & 12217 & 273577 & 25946 & 378148 & 126450 \\
\hline
\end{tabular}




\begin{tabular}{|c|c|c|c|c|c|c|c|c|c|c|c|c|}
\hline & & & & & & & $(\mathbf{F})$ & & $(\uparrow 2.3)$ & & (n.s.) & \\
\hline Pentanal** & 44 & 1 & n.d. & & n.d. & & n.d. & & $\begin{array}{l}33215 \\
(\mathbf{F}) \\
\end{array}$ & 5779 & $\begin{array}{l}43826 \\
(\uparrow \mathbf{1 . 3}) \\
\end{array}$ & 9274 \\
\hline 3-pentanone** & 86 & 2 & 26592 & 1995 & $\begin{array}{l}\text { n.d. } \\
(\mathbf{E})\end{array}$ & & n.d. & & n.d. & & n.d. & \\
\hline 1-penten-3-one* & 84 & 1 & 106239 & 19243 & $\begin{array}{l}\text { n.d. } \\
(\mathbf{E})\end{array}$ & & n.d. & & n.d. & & n.d. & \\
\hline 2-butenal & 70 & 1 & n.d. & & n.d. & & n.d. & & $\begin{array}{l}106049 \\
(\mathbf{F})\end{array}$ & 23205 & $\begin{array}{l}40958 \\
(\downarrow \mathbf{2 . 6}) \\
\end{array}$ & 5853 \\
\hline hexanal** & 82 & 1 & 4665 & 1215 & $\begin{array}{l}5575 \\
\text { (n.s.) }\end{array}$ & 1431 & $\begin{array}{l}2542 \\
(\downarrow \mathbf{2 . 2})\end{array}$ & 284 & $\begin{array}{l}4582 \\
(\uparrow \mathbf{1 . 8})\end{array}$ & 895 & $\begin{array}{l}6446 \\
(\uparrow 1.4)\end{array}$ & 1646 \\
\hline (E)-2-pentenal* & 55 & 1 & 30985 & 6716 & $\begin{array}{l}\text { n.d. } \\
\text { (E) }\end{array}$ & & n.d. & & n.d. & & n.d. & \\
\hline 3-hexenal* & 69 & 2 & 165403 & 7967 & $\begin{array}{l}\text { n.d. } \\
(\mathbf{E})\end{array}$ & & n.d. & & n.d. & & n.d. & \\
\hline 2-ethyl-2-butenal & 98 & 2 & n.d. & & n.d. & & n.d. & & $\begin{array}{l}23257 \\
\text { (F) } \\
\end{array}$ & 2151 & $\begin{array}{l}29206 \\
\text { (n.s.) }\end{array}$ & 10897 \\
\hline (E)-2-hexenal* & 83 & 1 & 171772 & 39327 & $\begin{array}{l}\text { n.d. } \\
(\mathbf{E})\end{array}$ & & n.d. & & n.d. & & n.d. & \\
\hline 2-vinyl-2-butenal & 67 & 2 & n.d. & & n.d. & & n.d. & & $\begin{array}{l}291124 \\
\text { (F) }\end{array}$ & 23095 & $\begin{array}{l}40830 \\
(\downarrow 7.1)\end{array}$ & 9883 \\
\hline octanal & 84 & 1 & n.d. & & $\begin{array}{l}9228 \\
(\mathbf{F})\end{array}$ & 3425 & $\begin{array}{l}5601 \\
\text { (n.s.) } \\
\end{array}$ & 1121 & $\begin{array}{l}11991 \\
(\uparrow \mathbf{2 . 1})\end{array}$ & 1260 & $\begin{array}{l}8138 \\
(\downarrow \mathbf{1 . 5})\end{array}$ & 2019 \\
\hline 2-heptenal & 83 & 1 & n.d. & & n.d. & & $\begin{array}{l}9464 \\
(\mathbf{F})\end{array}$ & 1291 & $\begin{array}{l}29948 \\
(\uparrow 3.2) \\
\end{array}$ & 3080 & $\begin{array}{l}16296 \\
(\downarrow \mathbf{1 . 8}) \\
\end{array}$ & 3451 \\
\hline nonanal & 98 & 1 & n.d. & & $\begin{array}{l}3075 \\
(\mathbf{F}) \\
\end{array}$ & 846 & $\begin{array}{l}4214 \\
\text { (n.s.) } \\
\end{array}$ & 1321 & $\begin{array}{l}5643 \\
\text { (n.s.) } \\
\end{array}$ & 771 & $\begin{array}{l}5607 \\
\text { (n.s.) } \\
\end{array}$ & 1296 \\
\hline$(\mathrm{E}, \mathrm{E})-2,4$-hexadienal & 81 & 1 & 43743 & 8801 & $\begin{array}{l}\text { n.d. } \\
(\mathbf{E})\end{array}$ & & n.d. & & n.d. & & n.d. & \\
\hline (E)-2-octenal & 55 & 1 & n.d. & & 4552 & 721 & 3635 & 247 & 6025 & 613 & 4160 & 691 \\
\hline
\end{tabular}




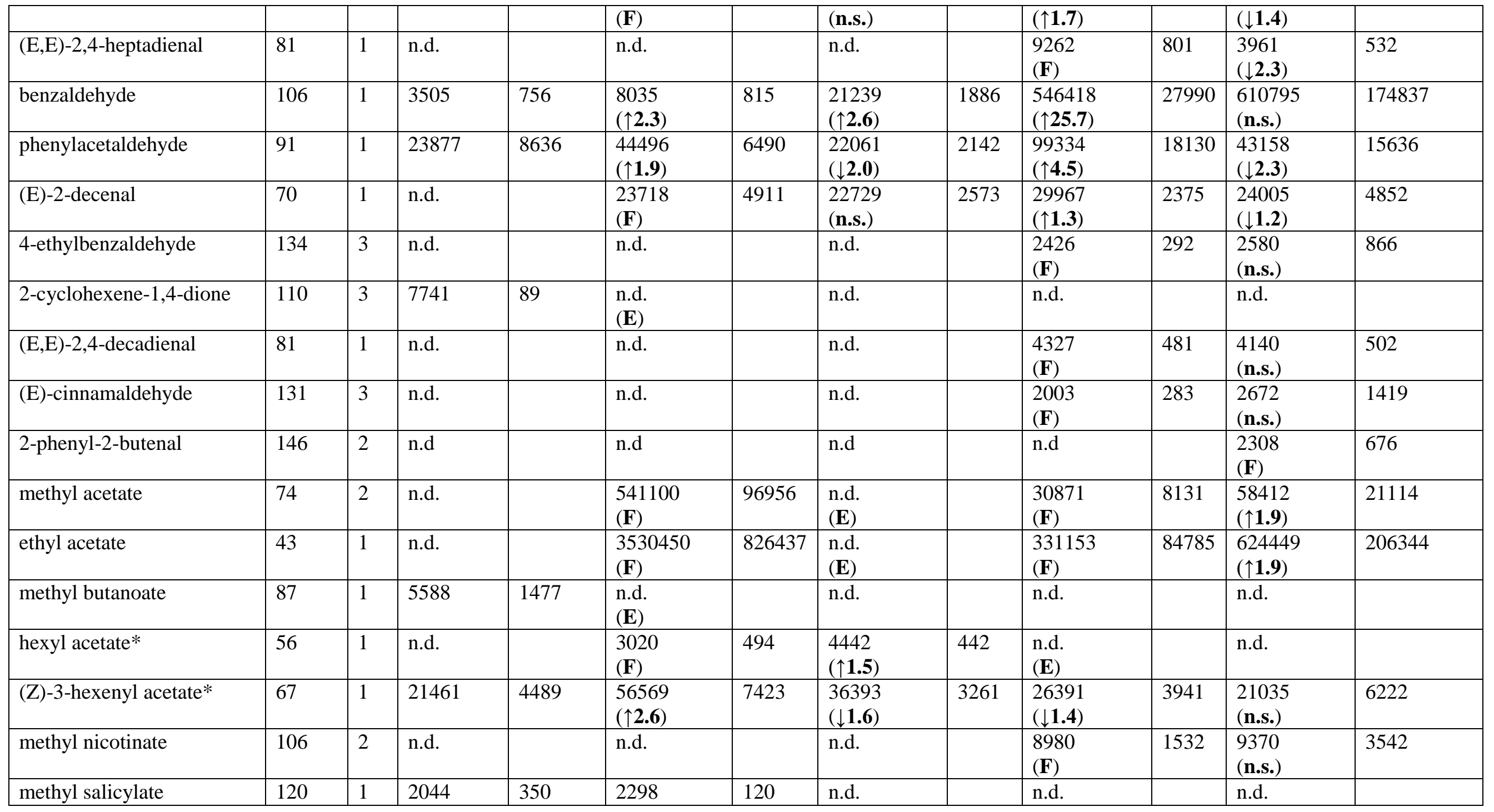




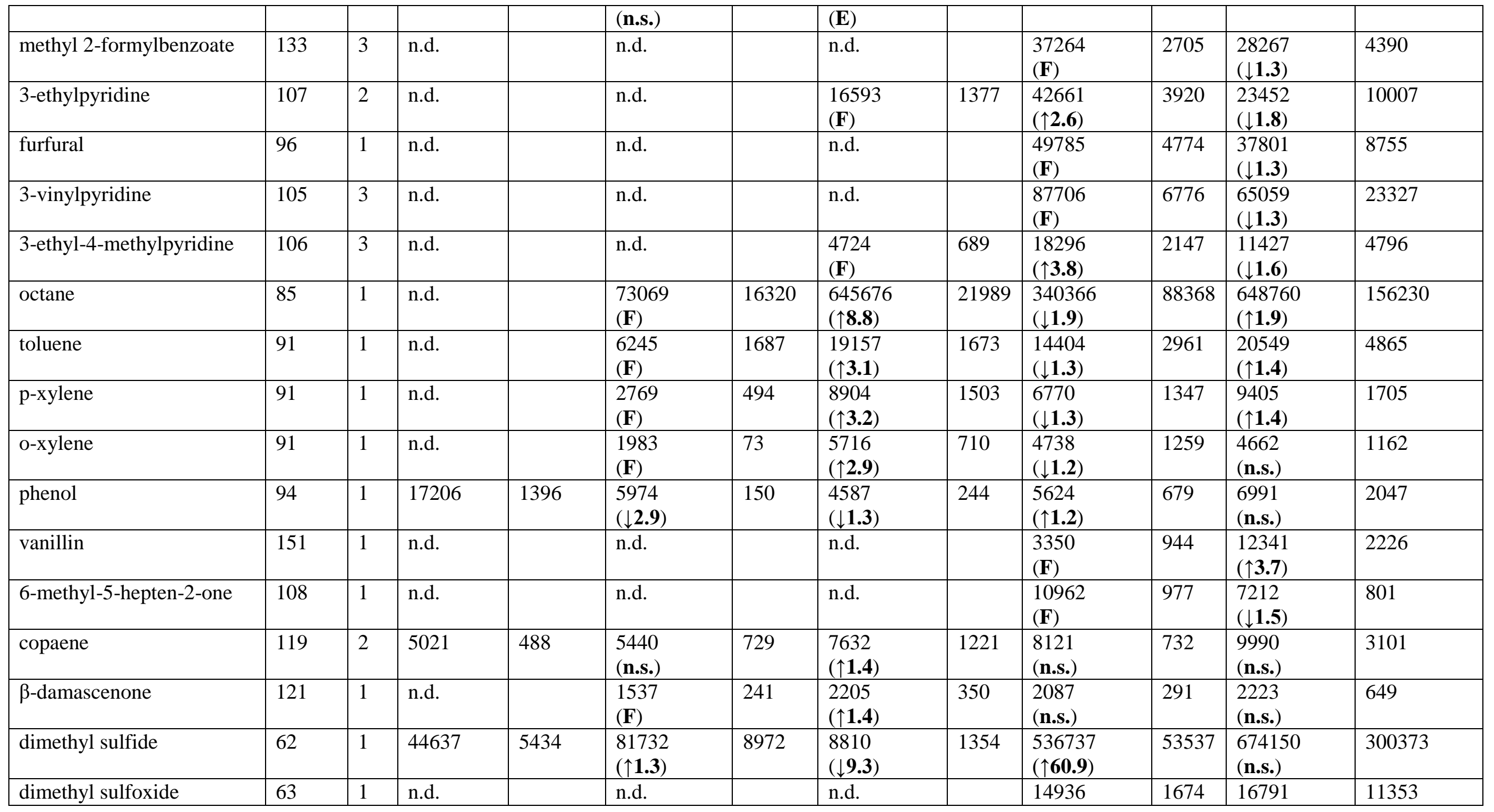




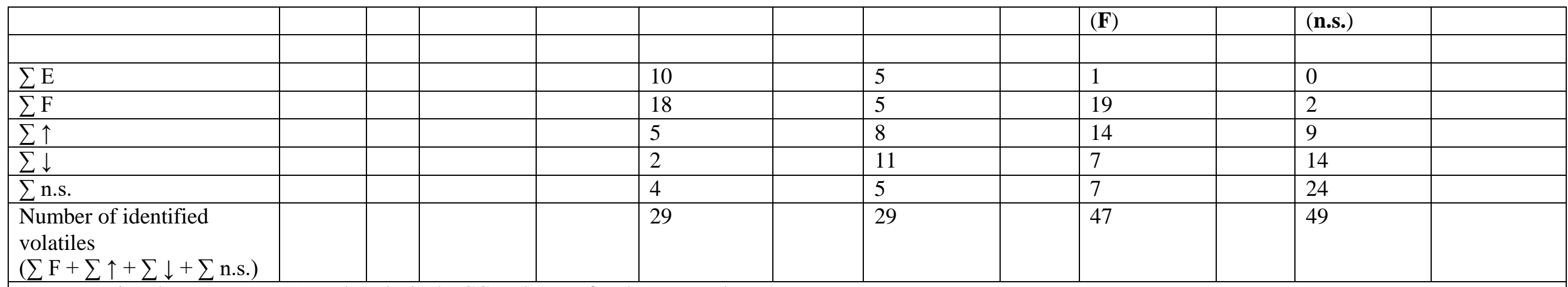

${ }^{\text {a }}$ Ion extraction chromatogram, $\mathrm{m} / \mathrm{z}$ used to obtain the GC peak area of each compound.

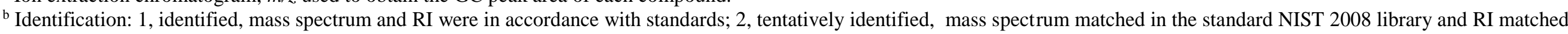
with literature; 3 , tentatively identified, mass spectrum agreed with the standard NIST 2008.

${ }^{\mathrm{c}}$ Standard deviation $(\mathrm{n}=3)$.

${ }^{\mathrm{d}}$ Standard deviation ( $\mathrm{n}=9,3$ bottles analyzed in triplicate).

n.d. $=$ not detected

${ }^{\mathrm{e}}$ Most acetic acid was from the preservation liquid used. Possible acetic acid formed by acetic acid bacteria was unknown.

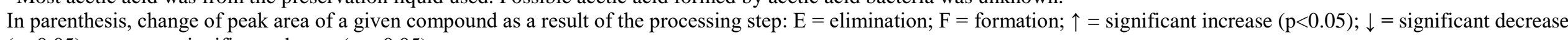
$(\mathrm{p}<0.05) ;$ n.s. $=$ not significant change $(\mathrm{p}>0.05)$

*Compound produced in fresh olives by LOX action from linolenic acid.**Compound produced in fresh olives by LOX action from linoleic acid. 


\begin{tabular}{|c|c|c|c|c|c|c|c|c|c|c|c|c|}
\hline \multirow[b]{2}{*}{ Compound } & \multirow[b]{2}{*}{$\begin{array}{l}\text { IEC } \\
(\mathrm{m} / \mathrm{z})^{\mathrm{a}}\end{array}$} & \multirow[b]{2}{*}{$\mathrm{ID}^{\mathrm{b}}$} & \multicolumn{2}{|c|}{ Fresh fruit } & \multicolumn{2}{|c|}{ After preservation } & \multicolumn{2}{|c|}{ After darkening } & \multicolumn{2}{|c|}{ After packing } & \multicolumn{2}{|c|}{ After storage } \\
\hline & & & $\begin{array}{l}\text { Average } \\
\text { area }\end{array}$ & $\mathrm{SD}^{\mathrm{c}}$ & $\begin{array}{l}\text { Average } \\
\text { area }\end{array}$ & $\mathrm{SD}^{\mathrm{c}}$ & $\begin{array}{l}\text { Average } \\
\text { area }\end{array}$ & $\mathrm{SD}^{\mathrm{c}}$ & $\begin{array}{l}\text { Average } \\
\text { area }\end{array}$ & $\mathrm{SD}^{\mathrm{d}}$ & $\begin{array}{l}\text { Average } \\
\text { area }\end{array}$ & $\mathrm{SD}^{\mathrm{d}}$ \\
\hline acetic acid & 60 & 1 & n.d. & & $\begin{array}{l}5311790^{\mathrm{e}} \\
(\mathbf{F})\end{array}$ & 1112149 & $\begin{array}{l}\text { n.d. } \\
\text { (E) }\end{array}$ & & n.d. & & n.d. & \\
\hline benzoic acid & 105 & 1 & n.d. & & n.d. & & n.d. & & $\begin{array}{l}26563 \\
(\mathbf{F}) \\
\end{array}$ & 6672 & $\begin{array}{l}13888 \\
(\downarrow \mathbf{1 . 9}) \\
\end{array}$ & 1658 \\
\hline ethanol & 45 & 1 & n.d. & & $\begin{array}{l}667130 \\
(\mathbf{F})\end{array}$ & 59400 & $\begin{array}{l}\text { n.d. } \\
\text { (E) }\end{array}$ & & $\begin{array}{l}71001 \\
(\mathbf{F})\end{array}$ & 19414 & $\begin{array}{l}79511 \\
\text { (n.s.) }\end{array}$ & 4310 \\
\hline 1-penten-3-ol* & 57 & 1 & 153220 & 5454 & $\begin{array}{l}\text { n.d. } \\
\text { (E) }\end{array}$ & & n.d. & & n.d. & & n.d. & \\
\hline isopentanol & 55 & 1 & n.d. & & $\begin{array}{l}15006 \\
(\mathbf{F})\end{array}$ & 2576 & $\begin{array}{l}\text { n.d. } \\
\text { (E) }\end{array}$ & & n.d. & & 5680 & 1004 \\
\hline 1 -pentanol** & 55 & 1 & 3304 & 572 & $\begin{array}{l}\text { n.d. } \\
(\mathbf{E})\end{array}$ & & $\begin{array}{l}1978 \\
(\mathbf{F})\end{array}$ & 659 & $\begin{array}{l}3356 \\
(\uparrow 1.7) \\
\end{array}$ & 533 & $\begin{array}{l}5844 \\
(\uparrow 1.7) \\
\end{array}$ & 998 \\
\hline (E)-2-penten-1-ol* & 86 & 2 & 892 & 144 & $\begin{array}{l}\text { n.d. } \\
(\mathbf{E})\end{array}$ & & n.d. & & n.d. & & n.d. & \\
\hline (Z)-2-penten-1-ol* & 68 & 2 & 53754 & 1115 & $\begin{array}{l}\text { n.d. } \\
\text { (E) }\end{array}$ & & n.d. & & n.d. & & n.d. & \\
\hline 1-hexanol** & 56 & 1 & 65176 & 1530 & $\begin{array}{l}15636 \\
(\downarrow 4.2) \\
\end{array}$ & 2136 & $\begin{array}{l}5245 \\
(\downarrow \mathbf{3 . 0}) \\
\end{array}$ & 906 & $\begin{array}{l}4195 \\
\text { (n.s.) } \\
\end{array}$ & 504 & $\begin{array}{l}5441 \\
(\uparrow \mathbf{1 . 3}) \\
\end{array}$ & 666 \\
\hline (E)-3-hexen-1-ol* & 67 & 2 & 4124 & 312 & $\begin{array}{l}\text { n.d. } \\
(\mathbf{E})\end{array}$ & & n.d. & & n.d. & & n.d. & \\
\hline (Z)-3-hexen-1-ol* & 67 & 1 & 801570 & 45006 & $\begin{array}{l}22431 \\
(\downarrow \mathbf{3 5 . 7})\end{array}$ & 3669 & $\begin{array}{l}8428 \\
(\downarrow 2.7) \\
\end{array}$ & 1143 & $\begin{array}{l}6516 \\
(\downarrow 1.3) \\
\end{array}$ & 684 & $\begin{array}{l}5582 \\
(\downarrow 1.2) \\
\end{array}$ & 784 \\
\hline (E)-2-hexen-1-ol* & 82 & 2 & 3437 & 339 & $\begin{array}{l}\text { n.d. } \\
(\mathbf{E})\end{array}$ & & n.d. & & n.d. & & n.d. & \\
\hline 1-heptanol & 70 & 1 & n.d. & & n.d. & & n.d. & & n.d. & & $\begin{array}{l}2728 \\
(\mathbf{F})\end{array}$ & 575 \\
\hline 1-octanol & 84 & 1 & n.d. & & 2154 & 4 & 2067 & 506 & 3553 & 260 & 2762 & 394 \\
\hline
\end{tabular}




\begin{tabular}{|c|c|c|c|c|c|c|c|c|c|c|c|c|}
\hline & & & & & $(\mathbf{F})$ & & (n.s.) & & $(\uparrow 1.7)$ & & $(\downarrow 1.3)$ & \\
\hline benzyl alcohol & 108 & 1 & 3275 & 520 & $\begin{array}{l}4842 \\
(\uparrow \mathbf{1 . 5})\end{array}$ & 350 & $\begin{array}{l}3061 \\
(\downarrow \mathbf{1 . 6})\end{array}$ & 418 & $\begin{array}{l}4690 \\
(\uparrow 1.5)\end{array}$ & 496 & $\begin{array}{l}5507 \\
(\uparrow 1.2) \\
\end{array}$ & 632 \\
\hline phenylethyl alcohol & 91 & 1 & 7652 & 682 & $\begin{array}{l}16912 \\
(\uparrow 2.2) \\
\end{array}$ & 2135 & $\begin{array}{l}5133 \\
(\downarrow 3.3)\end{array}$ & 677 & $\begin{array}{l}6956 \\
(\uparrow 1.4) \\
\end{array}$ & 1196 & $\begin{array}{l}8290 \\
(\uparrow \mathbf{1 . 2})\end{array}$ & 1102 \\
\hline 2-methylpropanal & 72 & 2 & n.d. & & n.d. & & n.d. & & $\begin{array}{l}23350 \\
(\mathbf{F})\end{array}$ & 8055 & $\begin{array}{l}45209 \\
(\uparrow \mathbf{1 . 9})\end{array}$ & 4747 \\
\hline 2-methylbutanal & 57 & 1 & n.d. & & n.d. & & $\begin{array}{l}46823 \\
(\mathbf{F})\end{array}$ & 5005 & $\begin{array}{l}156245 \\
(\uparrow 3.3)\end{array}$ & 26759 & $\begin{array}{l}287997 \\
(\uparrow \mathbf{1 . 8})\end{array}$ & 48071 \\
\hline 3-methylbutanal & 44 & 2 & n.d. & & n.d. & & $\begin{array}{l}73057 \\
(\mathbf{F})\end{array}$ & 19173 & $\begin{array}{l}281857 \\
(\uparrow \mathbf{3 . 9})\end{array}$ & 57034 & $\begin{array}{l}398226 \\
(\uparrow \mathbf{1 . 4})\end{array}$ & 79697 \\
\hline pentanal $* *$ & 44 & 1 & n.d. & & n.d. & & n.d. & & $\begin{array}{l}54722 \\
(\mathbf{F})\end{array}$ & 12084 & $\begin{array}{l}64359 \\
\text { (n.s.) }\end{array}$ & 13688 \\
\hline 3-pentanone $* *$ & 86 & 2 & 35997 & 2797 & $\begin{array}{l}\text { n.d. } \\
\text { (E) }\end{array}$ & & n.d. & & n.d. & & n.d. & \\
\hline 1-penten-3-one* & 82 & 2 & 212264 & 8094 & $\begin{array}{l}\text { n.d. } \\
\text { (E) }\end{array}$ & & n.d. & & n.d. & & n.d. & \\
\hline hexanal** & 82 & 1 & 49405 & 5115 & $\begin{array}{l}12756 \\
(\downarrow 3.9) \\
\end{array}$ & 6121 & $\begin{array}{l}1793 \\
(\downarrow 7.1)\end{array}$ & 371 & $\begin{array}{l}3820 \\
(\uparrow \mathbf{2 . 1})\end{array}$ & 1101 & $\begin{array}{l}3879 \\
\text { (n.s.) }\end{array}$ & 839 \\
\hline (E)-2-pentenal* & 55 & 1 & 85913 & 4668 & $\begin{array}{l}\text { n.d. } \\
(\mathbf{E})\end{array}$ & & n.d. & & n.d. & & n.d. & \\
\hline 2-ethyl-2-butenal & 98 & 2 & n.d. & & n.d. & & n.d. & & $\begin{array}{l}34243 \\
(\mathbf{F})\end{array}$ & 4325 & $\begin{array}{l}46277 \\
(\uparrow 1.4) \\
\end{array}$ & 8213 \\
\hline 3-hexenal* & 69 & 2 & 307210 & 28151 & $\begin{array}{l}\text { n.d. } \\
(\mathbf{E})\end{array}$ & & n.d. & & n.d. & & n.d. & \\
\hline heptanal & 70 & 1 & n.d. & & $\begin{array}{l}8385 \\
(\mathbf{F}) \\
\end{array}$ & 3128 & $\begin{array}{l}3065 \\
\text { (n.s.) } \\
\end{array}$ & 532 & $\begin{array}{l}3362 \\
\text { (n.s.) } \\
\end{array}$ & 1006 & $\begin{array}{l}4069 \\
\text { (n.s.) } \\
\end{array}$ & 788 \\
\hline (E)-2-hexenal* & 83 & 1 & 377158 & 16098 & $\begin{array}{l}\text { n.d. } \\
\text { (E) }\end{array}$ & & n.d. & & n.d. & & n.d. & \\
\hline octanal & 84 & 1 & n.d. & & 6803 & 1243 & 2777 & 948 & 10590 & 1797 & 6318 & 1627 \\
\hline
\end{tabular}




\begin{tabular}{|c|c|c|c|c|c|c|c|c|c|c|c|c|}
\hline & & & & & $(\mathbf{F})$ & & (n.S.) & & $(\uparrow 3.8)$ & & $(\downarrow 1.7)$ & \\
\hline 2-heptenal & 83 & 1 & n.d. & & n.d. & & n.d. & & $\begin{array}{l}26063 \\
\text { (F) }\end{array}$ & 6018 & $\begin{array}{l}16318 \\
(\downarrow \mathbf{1 . 6})\end{array}$ & 8365 \\
\hline nonanal & 98 & 1 & n.d. & & $\begin{array}{l}7000 \\
(\mathbf{F})\end{array}$ & 1718 & $\begin{array}{l}9876 \\
\text { (n.s.) }\end{array}$ & 3135 & $\begin{array}{l}6804 \\
\text { (n.s.) }\end{array}$ & 1055 & $\begin{array}{l}5717 \\
(\downarrow \mathbf{1 . 2})\end{array}$ & 680 \\
\hline (E,E)-2,4-hexadienal & 81 & 1 & 74437 & 4565 & $\begin{array}{l}\text { n.d. } \\
\text { (E) }\end{array}$ & & n.d. & & n.d. & & n.d. & \\
\hline (E)-2-octenal & 55 & 1 & n.d. & & n.d. & & n.d. & & $\begin{array}{l}3984 \\
(\mathbf{F})\end{array}$ & 494 & $\begin{array}{l}1472 \\
(\downarrow 2.7)\end{array}$ & 603 \\
\hline (E,E)-2,4-heptadienal & 81 & 1 & 6794 & 1163 & $\begin{array}{l}\text { n.d. } \\
\text { (E) }\end{array}$ & & n.d. & & $\begin{array}{l}13915 \\
(\mathbf{F})\end{array}$ & 2140 & $\begin{array}{l}\text { n.d. } \\
(\mathbf{E})\end{array}$ & \\
\hline benzaldehyde & 106 & 1 & 5441 & 719 & $\begin{array}{l}11712 \\
(\uparrow 2.2)\end{array}$ & 1912 & $\begin{array}{l}18383 \\
(\uparrow \mathbf{1 . 6})\end{array}$ & 2472 & $\begin{array}{l}1453748 \\
(\uparrow 79.1)\end{array}$ & 162202 & $\begin{array}{l}1491048 \\
\text { (n.s.) }\end{array}$ & 147487 \\
\hline phenylacetaldehyde & 91 & 1 & 22655 & 3232 & $\begin{array}{l}77383 \\
(\uparrow \mathbf{3 . 4})\end{array}$ & 12668 & $\begin{array}{l}\text { n.d. } \\
\text { (E) }\end{array}$ & & n.d. & & n.d. & \\
\hline (E)-2-decenal & 70 & 1 & n.d. & & n.d. & & n.d. & & $\begin{array}{l}14521 \\
(\mathbf{F})\end{array}$ & 3291 & $\begin{array}{l}5715 \\
(\downarrow 2.5) \\
\end{array}$ & 1769 \\
\hline 2-cyclohexene-1,4-dione & 110 & 3 & 11933 & 422 & $\begin{array}{l}\text { n.d. } \\
\text { (E) }\end{array}$ & & n.d. & & n.d. & & n.d. & \\
\hline (E,E)-2,4-decadienal & 81 & 1 & n.d. & & n.d. & & n.d. & & $\begin{array}{l}11063 \\
(\mathbf{F})\end{array}$ & 2097 & $\begin{array}{l}5980 \\
(\downarrow \mathbf{1 . 9})\end{array}$ & 943 \\
\hline (E)-cinnamaldehyde & 131 & 3 & n.d. & & n.d. & & n.d. & & $\begin{array}{l}9468 \\
(\mathbf{F})\end{array}$ & 2318 & $\begin{array}{l}5820 \\
(\downarrow \mathbf{1 . 6})\end{array}$ & 515 \\
\hline 2-phenyl-2-butenal & 146 & 2 & n.d. & & n.d. & & n.d. & & n.d. & & $\begin{array}{l}7360 \\
(\mathbf{F})\end{array}$ & 1347 \\
\hline methyl acetate & 74 & 2 & n.d. & & $\begin{array}{l}352778 \\
(\mathbf{F})\end{array}$ & 101979 & $\begin{array}{l}\text { n.d. } \\
\text { (E) }\end{array}$ & & $\begin{array}{l}49675 \\
(\mathbf{F})\end{array}$ & 15633 & $\begin{array}{l}82915 \\
(\uparrow \mathbf{1 . 7})\end{array}$ & 7297 \\
\hline ethyl acetate & 43 & 1 & n.d. & & $\begin{array}{l}2821549 \\
\text { (F) }\end{array}$ & 561253 & $\begin{array}{l}\text { n.d. } \\
\text { (E) }\end{array}$ & & $\begin{array}{l}490998 \\
\text { (F) }\end{array}$ & 140914 & $\begin{array}{l}908550 \\
(\uparrow \mathbf{1 . 9})\end{array}$ & 111322 \\
\hline methyl butanoate & 87 & 1 & 3740 & 216 & n.d. & & n.d. & & n.d. & & n.d. & \\
\hline
\end{tabular}




\begin{tabular}{|c|c|c|c|c|c|c|c|c|c|c|c|c|}
\hline & & & & & $(\mathbf{E})$ & & & & & & & \\
\hline hexyl acetate* & 56 & 1 & n.d. & & $\begin{array}{l}6673 \\
(\mathbf{F}) \\
\end{array}$ & 578 & $\begin{array}{l}5267 \\
(\downarrow \mathbf{1 . 3}) \\
\end{array}$ & 248 & $\begin{array}{l}3371 \\
(\downarrow \mathbf{1 . 6}) \\
\end{array}$ & 776 & $\begin{array}{l}3245 \\
\text { (n.s.) } \\
\end{array}$ & 518 \\
\hline (Z)-3-hexenyl acetate* & 67 & 1 & 23274 & 3636 & $\begin{array}{l}122227 \\
(\uparrow \mathbf{5 . 3})\end{array}$ & 9822 & $\begin{array}{l}34783 \\
(\downarrow 3.5) \\
\end{array}$ & 5036 & $\begin{array}{l}23235 \\
(\downarrow \mathbf{1 . 5}) \\
\end{array}$ & 4724 & $\begin{array}{l}24189 \\
\text { (n.s.) }\end{array}$ & 2201 \\
\hline methyl nicotinate & 106 & 2 & n.d. & & n.d. & & n.d. & & $\begin{array}{l}4484 \\
\text { (F) }\end{array}$ & 527 & $\begin{array}{l}3850 \\
\text { (n.s.) }\end{array}$ & 903 \\
\hline methyl salicylate & 120 & 1 & 7918 & 740 & $\begin{array}{l}5625 \\
(\downarrow 1.4) \\
\end{array}$ & 334 & $\begin{array}{l}1178 \\
(\downarrow 4.8) \\
\end{array}$ & 188 & $\begin{array}{l}\text { n.d. } \\
\text { (E) }\end{array}$ & & n.d. & \\
\hline ethyl salicylate & 120 & 1 & n.d. & & $\begin{array}{l}7383 \\
(\mathbf{F}) \\
\end{array}$ & 384 & $\begin{array}{l}3098 \\
(\downarrow \mathbf{2 . 4})\end{array}$ & 238 & $\begin{array}{l}\text { n.d. } \\
\text { (E) }\end{array}$ & & n.d. & \\
\hline methyl 2-formylbenzoate & 133 & 3 & n.d. & & n.d. & & n.d. & & $\begin{array}{l}22118 \\
(\mathbf{F})\end{array}$ & 3320 & $\begin{array}{l}8066 \\
(\downarrow 2.7) \\
\end{array}$ & 1264 \\
\hline pyridine & 79 & 2 & n.d. & & n.d. & & n.d. & & $\begin{array}{l}22855 \\
(\mathbf{F})\end{array}$ & 1690 & $\begin{array}{l}26968 \\
(\uparrow \mathbf{1 . 2})\end{array}$ & 3970 \\
\hline 3-methylpyridine & 93 & 2 & n.d. & & n.d. & & n.d. & & $\begin{array}{l}60797 \\
(\mathbf{F})\end{array}$ & 11723 & $\begin{array}{l}103532 \\
(\uparrow \mathbf{1 . 7})\end{array}$ & 13556 \\
\hline furfural & 96 & 1 & n.d. & & n.d. & & n.d. & & $\begin{array}{l}64137 \\
(\mathbf{F})\end{array}$ & 4607 & $\begin{array}{l}31405 \\
(\downarrow \mathbf{2 . 0})\end{array}$ & 4291 \\
\hline 3-vinylpyridine & 105 & 3 & n.d. & & n.d. & & n.d. & & $\begin{array}{l}170329 \\
(\mathbf{F})\end{array}$ & 21245 & $\begin{array}{l}148106 \\
\text { (n.s.) }\end{array}$ & 23146 \\
\hline 3-ethyl-4-methylpyridine & 106 & 3 & n.d. & & n.d. & & $\begin{array}{l}6616 \\
(\mathbf{F})\end{array}$ & 1321 & $\begin{array}{l}71767 \\
(\uparrow \mathbf{1 0 . 8})\end{array}$ & 8252 & $\begin{array}{l}66204 \\
\text { (n.s.) }\end{array}$ & 9643 \\
\hline furfuryl alcohol & 98 & 2 & n.d. & & n.d. & & n.d. & & $\begin{array}{l}3427 \\
(\mathbf{F})\end{array}$ & 728 & $\begin{array}{l}6159 \\
(\uparrow \mathbf{1 . 8})\end{array}$ & 549 \\
\hline octane & 85 & 1 & n.d. & & $\begin{array}{l}14875 \\
(\mathbf{F})\end{array}$ & 1526 & $\begin{array}{l}95766 \\
(\uparrow \mathbf{6 . 4}) \\
\end{array}$ & 13503 & $\begin{array}{l}32307 \\
(\downarrow \mathbf{3 . 0}) \\
\end{array}$ & 4173 & $\begin{array}{l}104071 \\
(\uparrow \mathbf{3 . 2})\end{array}$ & 34155 \\
\hline toluene & 91 & 1 & n.d. & & $\begin{array}{l}160832 \\
(\mathbf{F})\end{array}$ & 17403 & $\begin{array}{l}74530 \\
(\downarrow 2.2) \\
\end{array}$ & 8037 & $\begin{array}{l}24565 \\
(\downarrow \mathbf{3 . 0}) \\
\end{array}$ & 6178 & $\begin{array}{l}13208 \\
(\downarrow \mathbf{1 . 9})\end{array}$ & 2864 \\
\hline p-xylene & 91 & 1 & n.d. & & 94636 & 12022 & 51572 & 6193 & 18623 & 5561 & 30961 & 9245 \\
\hline
\end{tabular}




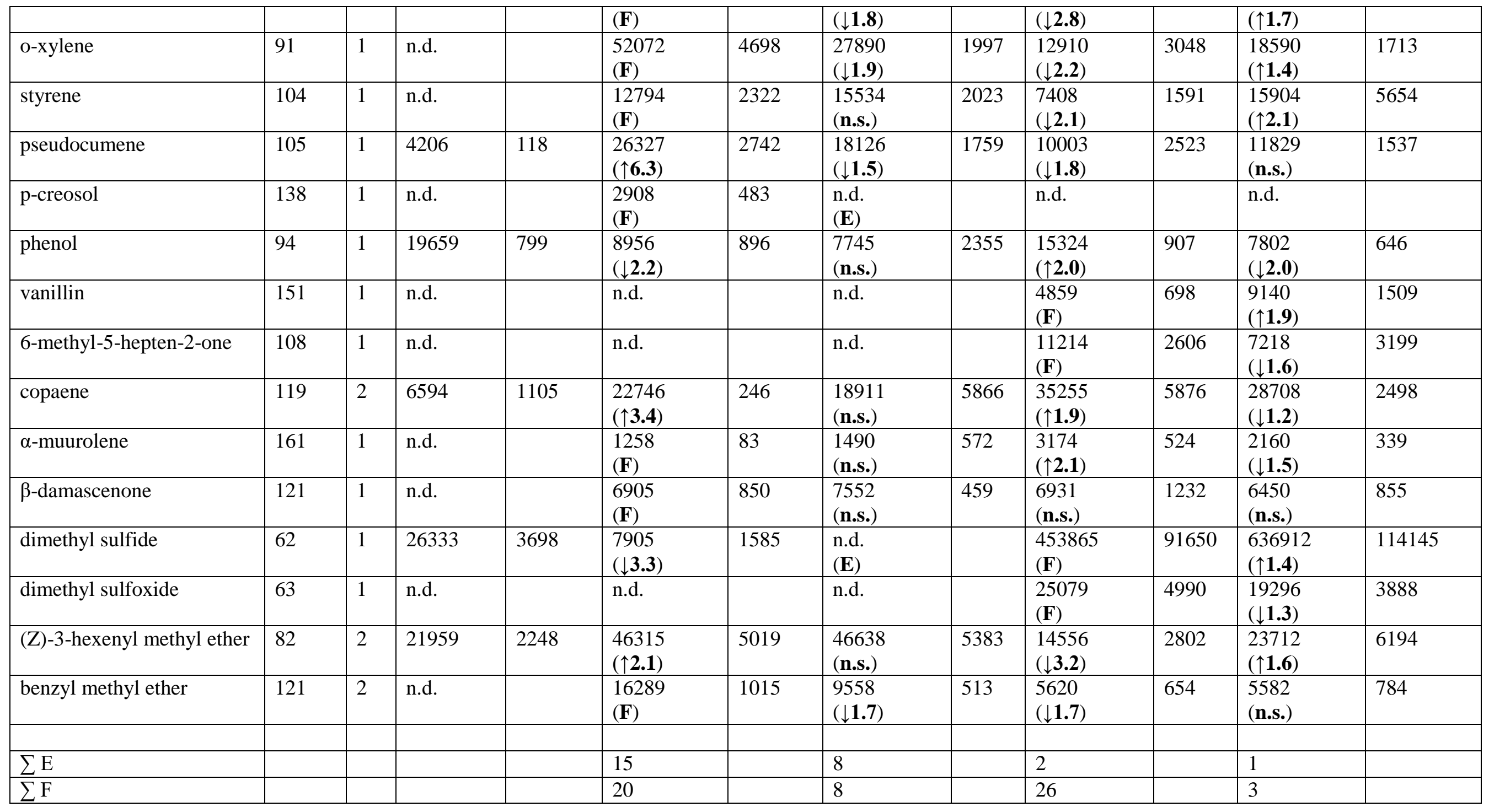




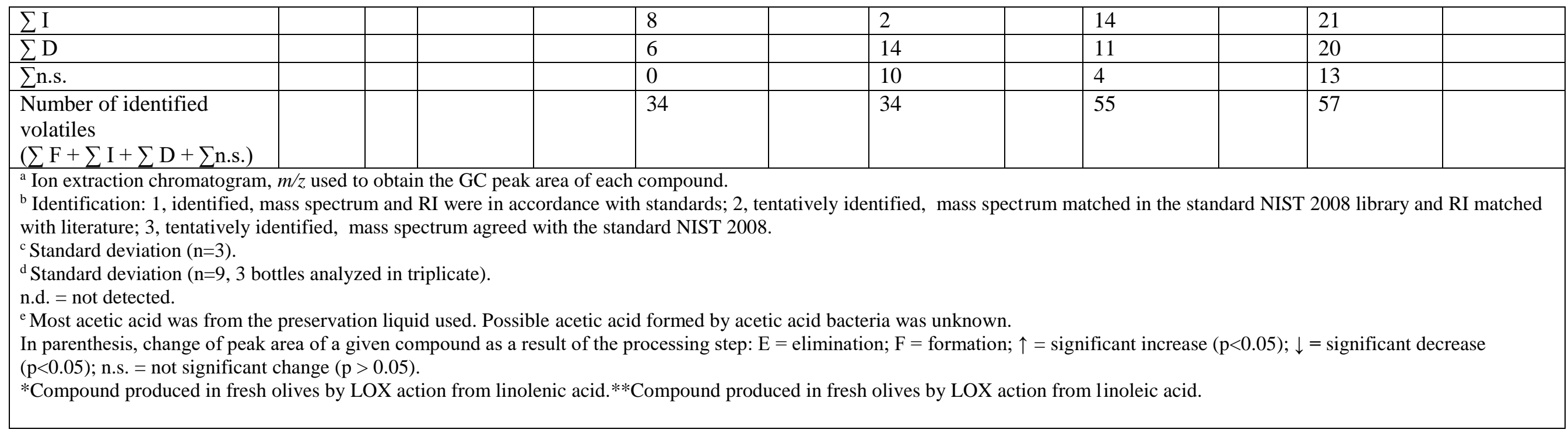


Table S3. Physico-chemical and microbiological characteristics of the preservation liquid of olives (Manzanilla and Hojiblanca cultivars) after 3 months of preservation

\begin{tabular}{lll}
\hline & Manzanilla & Hojiblanca \\
\hline Physico-chemical parameter & & \\
$\mathrm{pH}$ & 4.00 & 3.85 \\
Titratable acidity (\% acetic acid) & 1.49 & 1.40 \\
Combined acidity (N) & 0.074 & 0.066 \\
Microbial population $(\log \mathrm{cfu} / \mathrm{mL})$ & & \\
Lactic acid bacteria & n.d. & n.d. \\
Yeasts & 4.93 & 4.64 \\
Acetic acid bacteria & 4.85 & 4.74 \\
\hline n.d.= not detected (log cfu/mL $<1.3)$ & &
\end{tabular}


Table S4. Changes in physico-chemical characteristics of packing brines from Manzanilla and Hojiblanca ripe olives due to storage time ${ }^{a}$

\begin{tabular}{lllll}
\hline $\begin{array}{l}\text { Physico-chemical } \\
\text { parameter }\end{array}$ & \multicolumn{2}{l}{ Manzanilla ripe olives } & \multicolumn{2}{l}{ Hojiblanca ripe olives } \\
\hline & Initial $^{\mathrm{b}}$ & 8 months storage & Initial $^{\mathrm{b}}$ & 8 months storage \\
\hline $\mathrm{pH}$ & $6.12 \pm 0.05$ & $4.92 \pm 0.27$ & $6.71 \pm 0.02$ & $6.13 \pm 0.19$ \\
$\begin{array}{l}\text { Titratable acidity } \\
\left(\mathrm{g} \mathrm{L}^{-1} \text { lactic acid) }\right.\end{array}$ & $0.50 \pm 0.00$ & $2.80 \pm 0.26$ & $0.33 \pm 0.06$ & $0.77 \pm 0.23$ \\
$\begin{array}{l}\text { Combined acidity } \\
\left(\mathrm{eq} \mathrm{L}^{-1}\right)\end{array}$ & $0.037 \pm 0.002$ & $0.037 \pm 0.001$ & $0.054 \pm 0.002$ & $0.061 \pm 0.007$ \\
Salt $\left(\mathrm{g} \mathrm{L}^{-1} \mathrm{NaCl}\right)$ & $19.9 \pm 0.7$ & $17.5 \pm 0.8$ & $18.8 \pm 0.6$ & $16.3 \pm 0.3$ \\
\hline
\end{tabular}

a Values are means \pm SD of three replicate bottles

${ }^{b}$ After 15 days of storage 
